\title{
Spider-Ant Associations: An Updated Review of Myrmecomorphy, Myrmecophily, and Myrmecophagy in Spiders
}

\author{
Paula E. Cushing \\ Department of Zoology, Denver Museum of Nature \& Science, 2001 Colorado Boulevard, Denver, CO 80205, USA \\ Correspondence should be addressed to Paula E. Cushing, paula.cushing@dmns.org
}

Received 3 October 2011; Accepted 18 December 2011

Academic Editor: Jean Paul Lachaud

Copyright () 2012 Paula E. Cushing. This is an open access article distributed under the Creative Commons Attribution License, which permits unrestricted use, distribution, and reproduction in any medium, provided the original work is properly cited.

This paper provides a summary of the extensive theoretical and empirical work that has been carried out in recent years testing the adaptational significance of various spider-ant associations. Hundreds of species of spiders have evolved close relationships with ants and can be classified as myrmecomorphs, myrmecophiles, or myrmecophages. Myrmecomorphs are Batesian mimics. Their close morphological and behavioral resemblance to ants confers strong survival advantages against visually hunting predators. Some species of spiders have become integrated into the ant society as myrmecophiles or symbionts. These spider myrmecophiles gain protection against their own predators, live in an environment with a stable climate, and are typically surrounded by abundant food resources. The adaptations by which this integration is made possible are poorly known, although it is hypothesized that most spider myrmecophiles are chemical mimics and some are even phoretic on their hosts. The third type of spider-ant association discussed is myrmecophagy — or predatory specialization on ants. A table of known spider myrmecophages is provided as is information on their biology and hunting strategies. Myrmecophagy provides these predators with an essentially unlimited food supply and may even confer other protections to the spiders.

\section{Introduction}

The majority of spiders are solitary generalist predators of insects [1]. Most spiders, as with most arthropod predators, are averse to ant predation because ants are generally aggressive, some are venomous, and most are simply noxious for a variety of reasons [2]. Nevertheless, hundreds of arthropod species live in some level of proximity or association with ants [3-5]. The present paper supplements a review I published in 1997 [5] identifying and describing the biology of spiders that are found in association with ants. In the earlier article, I summarized what was then known about the biology and identities of ant-mimicking, or myrmecomorphic, spiders as well as spiders living in close proximity to or living within ant colonies, known as myrmecophiles. That review included tables listing known spider myrmecomorphs and myrmecophiles. The purpose of the present paper is not to replicate information contained in the 1997 article but, instead, to provide a summary of the extensive theoretical and empirical work that has been carried out in recent years testing the adaptational significance of the various spiderant associations. Additionally, I summarize instances of a different kind of spider-ant association-that of predatorprey relationships, or myrmecophagy-and provide a table of known species of spiders that feed on or specialize on ants.

\section{Spider Myrmecomorphy}

2.1. Morphological and Behavioral Adaptations. Morphological adaptations conferring mimetic resemblance to ants include color pattern similarities as well as more dramatic morphological changes such as abdominal constrictions and/or constriction of the cephalothorax, both of which give the illusion that the spider has more than two body parts [57] (Figures 1(a) and 1(b)). One recent paper demonstrated that some of these morphological adaptations may be synapomorphic for lineages [8], suggesting that at least some of the morphological adaptations associated with myrmecomorphy may be under phylogenetic constraint. Additional morphological adaptations seen in some spider myrmecomorphs include enlargement of the chelicerae or enlargement or other adaptations associated with the pedipalps or first legs. For example, males of some species of salticids in 


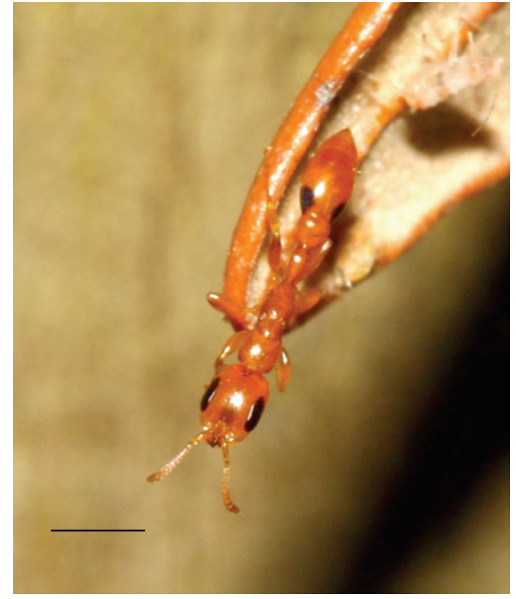

(a)

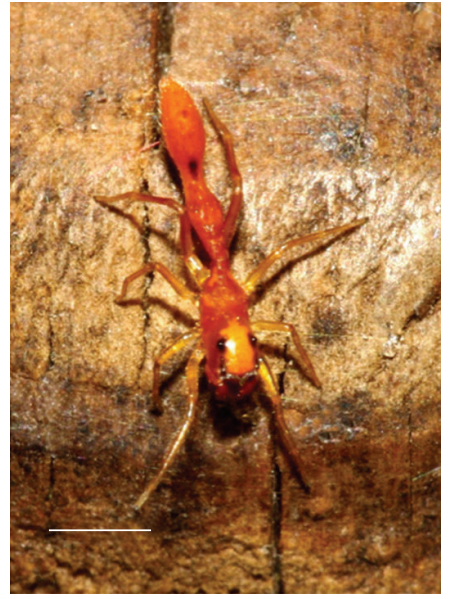

(b)

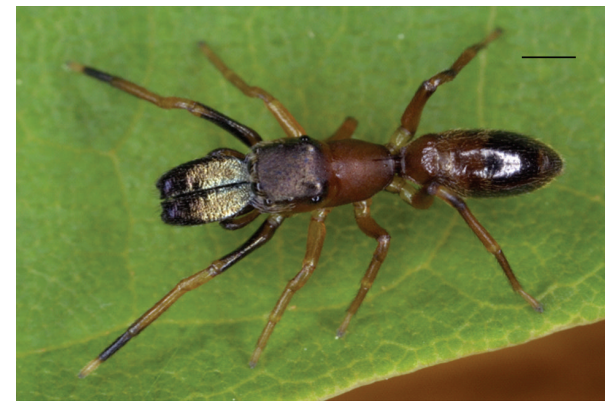

(c)

Figure 1: Myrmecomorphy in spiders. (a) The model ant Pseudomyrmex simplex (Smith) and its mimic, (b) Synemosyna petrunkevitchi (Chapin) (Salticidae). Photos @ Lyn Atherton, used by permission. (c) Myrmarachne formicaria (De Geer) (Salticidae) showing the enlarged chelicerae of the male. Photo $\odot$ Jay Cossey/PhotographsFromNature.com, used by permission. Scale bars $=1 \mathrm{~mm}$.

the genus Myrmarachne have greatly enlarged chelicerae that extend anteriorly [9] (Figure 1(c)). These large chelicerae are thought to have evolved via sexual selection [10]. Recent research demonstrated that male Myrmarachne with enlarged chelicerae mimic encumbered ants (worker ants carrying items in their mandibles) $[11,12]$. In the myrmecomorphic species in the family Corinnidae, Pranburia mahannopi Deeleman-Reinhold, the first pair of legs of males has a thick brush of setae around the distal part of the femora. When the spider is disturbed or alarmed, it brings the femora together and the brushes give the illusion of an ant head (i.e., the spider behaviorally and morphologically acquires a third body part [13]).

Spider myrmecomorphs resemble the model ants to varying degrees of accuracy. Some myrmecomorphs are, at least to the human observer, nearly perfect mimics; others generally resemble ants but no specific model species in the vicinity of the spider can be identified. The latter are termed "imperfect" or "inaccurate" mimics $[14,15]$. Some species of myrmecomorphic spiders are polymorphic mimics, mimicking multiple species of ants found in the habitat (see [5, Table 1], and $[9,16-20])$. One species of jumping spider (Salticidae), Myrmarachne bakeri Banks, is polymorphic in color patterns and individual spiders can even change patterns during the course their lives, even after molting to maturity [20]. Individuals can change their patterns even under constant environmental conditions and feeding regime [20]. Other myrmecomorphs are transformational mimics, mimicking different species of ants during their different developmental stages (see [5, Table 1], and $[9,16-18,21]$ ).

In addition to morphological resemblance to ants, most spider myrmecomorphs are also behavioral mimics (see citations in [5]). This behavioral mimicry includes erratic movement, much more akin to the movement of ants than the movement of spiders, and lifting the first or second pair of legs when moving through the environment as an antennal illusion [22]. Myrmecomorphic salticid spiders also hunt their prey by lunging at and sometimes tapping the prey rather than by leaping on it as is common in most nonmimetic salticids [11, 22-24]. In other words, these spiders maintain their resemblance to ants even when hunting.

\subsection{General Adaptive Significance of Myrmecomorphy. Myr-} mecomorphy has long been hypothesized to be an example of Batesian mimicry, conferring an adaptive advantage to the mimics against visually hunting arthropod predators that have either an innate or learned aversion to ants. Several studies have provided strong support for this hypothesis, demonstrating that myrmecomorphic spiders are less likely to be chosen as prey by visually hunting predators that would otherwise readily accept spiders [25-32]. In several of these studies, the predators used are naïve and have never encountered ants before, demonstrating that aversion to ants, at least in some arthropod predators, is innate rather than learned $[27,28,30]$. In order for myrmecomorphy to provide an adaptive advantage to the mimics, the mimics must live in close proximity to the models [33-38]. In addition, mimics should be rarer than models $[15,34,36,39,40]$.

However, myrmecomorphic spiders, particularly those in the salticid genus Myrmarachne, often live in high concentrations within a given area. For example, Myrmarachne melanotarsa Wesolowska and Salm lives in aggregated groups in which their silken nest complexes are in close association with nests of their model ant, Crematogaster sp. [24]. Since ants live in often very large colonies, it has been hypothesized that aggregations of myrmecomorphs are an example of "collective mimicry" in which the myrmecomorphic spiders are, by living in aggregated groups, mimicking the colonial aspects of the models. Groups of mimics may be perceived by predators as more aversive than single individuals found in the habitat $[24,29]$. A counter to this hypothesis is that the mimic may therefore outnumber the model in small areas of the habitat, making it more likely that predators will 
sample and learn the patterns of the palatable mimics and making Batesian mimicry less effective [34]. In some visually hunting spider predators, such as the wasp Pison xanthopus (Brulle) (Sphecidae), individuals can develop search images for myrmecomorphic spiders and stock proportionally more mimics in their mud cells than would be expected if the wasp was randomly hunting spiders in the environment [41]. Therefore, some predators are capable of learning to search for myrmecomorphs. However, in a study of the mud-dauber Sceliphron spirifex (L.), Jocqué found no myrmecomorphic spiders among almost 600 spiders removed from mud nests, despite Myrmarachne species being common in the habitat suggesting that, at least for this wasp, ant mimicry does provide protection from visually hunting predators [42].

Yet, it has been pointed out that mimics can still confer protection against predators even when they are more abundant than the model if certain conditions exist: (1) if the model is very noxious, then the predators will avoid good mimics regardless of the relative proportions of models and mimics; (2) if the mimic has low nutritional value and is, therefore, not worth pursuing; (3) if very profitable alternative prey are present in which case the predator will avoid both model and mimic regardless of the relative abundance of each; or (4) if the relative perception of abundance is different, for example, if the predator perceives the model as more abundant than the mimic (perhaps because of the higher activity levels of the models) [37].

2.3. Evolution of Polymorphic Mimicry. In recent years, researchers have explored the adaptive basis and the conditions under which polymorphic mimicry might arise. Theoretically, a mimic species should converge on mimetic resemblance of the single model species found in that habitat, particularly for predators that learn to avoid the model [37]. Yet many instances of polymorphic mimicry among spider myrmecomorphs have been documented (see citations in Section 2.1). Several hypotheses have been proposed to explain the existence of polymorphic mimics. For example, Ceccarelli and Crozier [43] suggested that the evolutionary rates between different morphs of the salticid Myrmarachne and their presumed models differ [43]. These authors demonstrated that morphs of the mimics radiated rapidly leading to higher degrees of polymorphism and provided evidence of possible sympatric speciation. Myrmarachne plataleoides (O. P.-Cambridge) mimics the weaver ant Oecophylla smaragdina (Fabricius). Borges et al. [19] showed that the different color morphs of M. plataleoides may mimic different models in the habitat besides O. smaragdina. Males of each color morph showed greatest interest in the silk retreats of females of their own color morph. Disruptive selection may be maintaining the polymorphism in this population [19]. In addition, it has been proposed that polymorphic mimicry, in essence, provides a "moving target" for template learning among visually hunting predators that learn to avoid aversive prey [44]. Nelson [44] proposed that polymorphism in a myrmecomorphic species reduces the apparent number of mimics per model. Therefore, predators cannot easily distinguish palatable mimics from the unpalatable models because the characteristics of the prey are continuously changing. The new mimetic form will be advantageous since it is rare, but if this morph increases too much in frequency within the habitat, it may lose its mimetic protection and be selected against [37]. This selective process itself may generate selection for new morphs [37].

Sexual dimorphism can be considered a type of polymorphism. In many cases of sexually dimorphic spider myrmecomorphs, the male is more mimetic than the female, such as in species of the Corinnidae genus Castianeira and the Oonopidae genus Antoonops [13, 45]. Such sexual dimorphism may be adaptive if the sexes are different in ecology and are thus exposed to different predation pressures and selective forces [46]. Joron [46] provides a model supporting this mode of evolution and selection for sexual dimorphism among mimetic species. Although mimics gain protection from the resemblance to noxious species, they are often more conspicuous in their color markings than related species that have evolved cryptic coloration. Thus conspicuousness can be considered a cost of Batesian mimicry [47]. A palatable species may be evolutionarily maximizing its level of protection for the smallest cost (in terms of conspicuousness) and this evolutionary balancing act may lead to sexual dimorphism in which the more active sex (which, in spiders, is typically the males) evolves mimetic resemblance to noxious models whereas the other sex remains relatively more concealed and camouflaged behaviorally and morphologically [47].

In some species of the salticid genus Myrmarachne, the males and females are both mimetic but the males have extraordinarily long chelicerae. This sex mimics ants carrying an object in their mandibles [11, 12]. The large chelicerae of males are thought to have evolved via sexual selection [10]. These large chelicerae are an encumbrance to males during prey capture; however, they make males much more efficient than females in breaking into other spiders' silken retreats and feeding on eggs or juveniles [10]. Consequently, in this case of sexual dimorphism, both sexes have maintained mimetic resemblance to the models, although the male is mimicking a slightly different type of model ant (an encumbered ant). Any costs incurred from the dimorphism may be outweighed by benefits in opening up a different trophic niche for the males (oophagy).

2.4. Evolution of Imperfect or Inaccurate Mimicry. It is well documented that many mimics are imperfect in their mimetic resemblance to the model. These species generally resemble the putative models but are not accurate mimics [14, $31,37,47,48]$. Some authors propose that poor mimics are just on an evolutionary trajectory towards perfection. This hypothesis is discussed by Edmunds [49] and Gilbert [37]. Gilbert [37] refutes this hypothesis saying, "In my view it is better to assume that poor mimetic patterns have evolved to an equilibrium state, rather than being in the process of being perfected by constant directional selection" since there is no experimental or theoretical support for the hypothesis that imperfect mimics are just mimics on their way towards perfection. 
Recently, authors have instead proposed various evolutionary scenarios that may select for imperfect or inaccurate mimicry rather than explain this phenomenon away as "evolution in progress." Many papers point out that if a model is extremely unpalatable, noxious, or difficult to capture, then even imperfect mimics will gain strong selective advantage from a general resemblance to this model and there may be no selective advantage or pressure for more accurate mimetic resemblance $[34,37,39,47,50]$. In fact, the fitness costs of close morphological resemblance (see Section 2.5) may select against accurate mimicry and may select for imperfect mimicry if either confers approximately the same selective advantage in terms of escape from predation. In a study by Duncan and Sheppard [50], the authors experimentally demonstrate that, when the model is very noxious, even imperfect mimics gain protection. However, when the model is only moderately distasteful, selection favors more accurate mimics. They showed that when the cost of making a mistake, attacking a distasteful model because it is mistaken for a palatable mimic, is high, the predator rejects a greater proportion of mimics and there is little selection for more accurate mimicry. When the penalty for making a mistake is low, tiny improvements in mimetic resemblance confer a selective advantage to the mimics, leading to more accurate mimicry [50]. In a study by Speed and Ruxton [47], the authors propose that if generalization by the selective agents (the predators) is narrow, selection towards accurate mimicry is predicted. If generalization by predators is relatively wide (e.g., in the case of a particularly noxious model), variations in mimetic forms may be selected for with both accurate and inaccurate mimics. Finally if generalization by predators is intermediate, then the rate of evolution selecting for accurate mimicry will be slow and polymorphic mimetic forms will be stable.

In situations in which the model either becomes rare or is weakly aversive and the incentive to attack and sample the models (by predators) is high, then close mimics may in fact be selected against. Kin selection among the mimetic population would select for less accurate mimics that diverge in their mimetic resemblance to the weakly defended model $[15,34,37]$. Inaccurate mimicry can also be favored in species with limited dispersal and high local abundance in which neighboring mimics are related (i.e., kin selection) [15].

A study by Kikuchi and Pfennig [39] provided experimental support for the hypothesis that evolution of accurate mimicry is a gradual process and depends on the relative abundance of the model. In this study, the authors found that in areas where the model was abundant, predators attacked cryptic (or camouflaged) prey, accurate mimics, and intermediate (or imperfect) mimics with the same low frequency. In other words, in areas where the model was abundant, predators generalize and imperfect mimics gain the same relative protection as more accurate mimics. In habitats where the model population was low, camouflaged species and mimics attained greater protection than imperfect mimics. Thus the authors showed that Batesian mimicry can evolve through gradual steps towards more accurate mimicry depending on conditions and context (particularly the abundance of models in the habitat) [39]. This study also suggests that mimics may have evolved from cryptic or camouflaged ancestors.

Accuracy of the mimetic resemblance may depend largely on the visual acuity of the selective agent. If predators with keen vision serve as the primary selective agents, then these predators may select for more accurate mimicry [34]. Then again, mimicry may be in the eyes of the beholder. Arthropods that humans view as poor mimics were perceived by pigeons, in an experimental test, as very good mimics [14]. Dittrich et al. [14] also showed that slight changes in the morphology of the mimic led to sometimes dramatic improvements, from the perspective of the selective agent, in perceived mimetic resemblance. They further pointed out that discrimination between a good and a poor mimic occurs via multiple features (e.g., color, form, size), not a single characteristic [14]. Other authors have also suggested that selection for increasingly better mimetic resemblance can, in fact, be a gradual process through directional selection $[50,51]$.

Related to the hypothesis that mimetic accuracy is dependent on the visual acuity of the selective agent is the multi-predator hypothesis, which proposes that inaccurate Batesian mimics evolved as a result of selective forces from a suite of predators [52]. For example, model averse predators select for more accurate morphological mimics in a given habitat while specialist predators on the model (e.g., ant predators or myrmecophages) select for inaccurate mimicry or for secondary defenses in the mimic [52]. Secondary defenses may include fast evasive movements by the mimics (quickly dropping all pretense of behavioral mimicry) or signaling the predator in such a way as to communicate its true identity [52]. If both kinds of predators are present in a habitat, there may be selection for inaccurate mimics or for polymorphic mimicry [52].

One hypothesis explaining imperfect Batesian mimicry that has gained some momentum in recent years is the multi-model hypothesis. If many potential model species live in a given habitat (e.g., many different species of ants), then it may be adaptive for the mimetic species to evolve a general, imperfect resemblance-a gestalt resemblanceto all of them than to evolve a specific morphological resemblance to a particular model $[33,37,49]$. For example, a general ant-mimicking spider in such a habitat can then have a much greater range than a spider that resembles only one of the potential models. If it is an accurate mimic, then its range is limited to the range of that one species in order to be an effective Batesian mimic. In one study, the authors found that some species of accurate ant mimics were found in association with a single model (measured as the closest ant collected where the spider was found). Some imperfect mimics (by human standards) were collected in proximity to more than one species of ant, conferring some support for the multi-model hypothesis [33]. However, in this same study, the author also found habitats in which accurate and inaccurate mimics did not associate with the models as predicted. 
2.5. Trade-Offs Affecting the Evolution of Myrmecomorphy. A close morphological resemblance to ants makes myrmecomorphs more attractive to ant predators or myrmecophages. Thus myrmecomorphs are faced with an evolutionary tradeoff: they gain protection from general arthropod predators but risk predation from a completely different suite of predators $([11,12,53]$ and citations above under discussion of multi-predator hypothesis). Many spider myrmecomorphs confront a threat from a myrmecophage by completely dropping their behavioral mimicry. These spiders will stop their erratic ant-like movement and run away, drop on a silk thread, signal to the predator in a spider-specific manner, or otherwise communicate their true identity to the predator $[11,52,54]$. This strategy is effective in allowing the spider to escape from the myrmecophage (or from ants that may confront it directly) $[11,24,54]$.

Myrmecomorphs face other costs that may affect their fitness, including (1) constraint of the circadian rhythm of the mimic since it must be active at the same time of day as the model for the resemblance to be adaptive; (2) an imposed limit to the myrmecomorph's trophic niche because it would only have access to prey that lived in the same habitat as the model; (3) a possible detrimental or costly effect on mating or reproduction since many myrmecomorphs must mate in a sheltered location, where their non-ant-like behavior will not "give the game away" or may mate for a shorter duration than non-mimetic relatives for the same reason; (4) a lowering of fecundity with the abdominal narrowing or constrictions often associated with myrmecomorphy and the resultant decrease in the number of eggs a female can produce $[37,55]$. It has been documented that narrower abdomens in female spiders limit the number of eggs that can be produced in comparison to non-mimetic relatives $[9,18,56-$ 61]. In addition, there may be a cost associated with alteration in the prey capture behaviors, such as those seen in myrmecomorphic salticids that lunge rather than jump upon their prey, which may be a much less effective prey capture strategy.

Nevertheless, if the primary predators demonstrate an innate, rather than learned, aversion to ants, the circadian rhythm of the myrmecomorphs may not be greatly affected and they can be active at any time of day. The limitation of trophic niches may not apply to general ant mimics since these spiders can exist, according to the multi-model hypothesis, across a potentially broad range of habitats. It does seem though that most spider myrmecomorphs do share the same habitat as their models and are active at the same time of day. It has even been pointed out that no species of wolf spider (family Lycosidae) has been reported to be an ant mimic because most lycosids are nocturnal and not active when visually hunting arthropod predators are most active [4]. Researchers investigating the inaccurate myrmecomorphs Liophrurillus flavitarsis (Lucas), Phrurolithus festivus (C. L. Koch) (both in the family Corinnidae), and Micaria sociabilis Kulczynski (Gnaphosidae) found that, in comparison to these species' closest relatives, the trophic niche of each was constrained by their resemblance to ants because they were limited to catching only small invertebrates found in the same habitat as the models. The circadian rhythms of these myrmecomorphs were also constrained because the myrmecomorphs were all diurnal (as were the models) but the closest relatives were nocturnal. However, the reproductive traits were not constrained since the fecundity of the inaccurate mimics was about the same as the non-mimetic relatives and the myrmecomorphs mated out in the open on bark, not dropping their behavioral mimicry when copulating [55].

The evolution of close morphological and behavioral mimicry of ants is costly and these costs should be measured as fitness components [37]. In addition, more studies should attempt to identify the operators or selective agents selecting for mimetic resemblance since the visual acuity of these selective agents (if they can be identified) may affect the accuracy of the resemblance. All these costs, trade-offs, and constraints should be taken into account when testing or modeling the adaptive significance of myrmecomorphy. The relative measures of the costs and benefits of mimetic resemblance may have a significant impact on the accuracy of the resemblance. If, for a particular species, the fitness costs of close mimetic resemblance due to lower fecundity greatly outweigh the benefits, then imperfect or inaccurate mimicry may be selected for. For example, in a habitat where the primary selective agent is a predator with low visual acuity, increased mimetic accuracy may impose a higher cost in terms of fecundity than is gained in terms of escape from predation. In small species of spiders in which greater mimetic resemblance would lead to dramatically lower fecundity due to a narrowing of the female's abdomen, dimorphic mimicry may be selected for and males may show greater mimetic resemblance than females. Too few models take into account fitness costs of mimetic resemblance and the relative effect such trade-offs may have on the evolution of imperfect, polymorphic, transformational, and dimorphic mimicry.

\section{Spider Myrmecophily}

3.1. Additional Records of Spider Myrmecophiles. Myrmecophiles are defined as ant guests, arthropods that have evolved close associations with ant species, often living alongside the ants or within the ant colonies [2, 3, 5, 62]. Some, but not many, of these myrmecophiles are also myrmecomorphs. Recent work (cited below) has found that, among spider myrmecophiles, some are also myrmecophages.

An extensive table of spider myrmecophiles was presented by Cushing [5]. Table 1 supplements this earlier table and provides records of spider myrmecophiles not included in the previous table. Not as much work has been carried out exploring the natural history, adaptations, or evolutionary significance of spider myrmecophiles as has been done with spider myrmecomorphs and myrmecophages. Nevertheless, some significant research has been conducted recently that expands our understanding of the biology of these interesting ant associates and how this unique lifestyle may have evolved in a group of arthropods that otherwise includes primarily free-living, solitary predators.

3.2. Adaptive Significance of Myrmecophily. An ant colony, as pointed out by Hölldobler and Wilson [2], can be considered 
TABLE 1: Spider myrmecophiles found in association with or inside ant nests. This table is meant to supplement the table of Araneae mymecophiles found in Cushing [5]. Spider taxonomy according to Platnick [63]; ant taxonomy according to http://antbase.org/.

\begin{tabular}{|c|c|c|c|}
\hline Spider myrmecophile & Ant host & Notes on biology & References \\
\hline \multicolumn{4}{|l|}{ Linyphiidae } \\
\hline Diastanillus pecuarius (Simon) & Formica cf. fusca L. and F. lemani Bondroit & Found under stone near ants. & {$[64,65]$} \\
\hline Pseudomaro aenigmaticus Denis & Lasius flavus (Fabricius) & Associated with nests. & [65] \\
\hline Syedra myrmicarum (Kulczynski) & Manica rubida (Latreille) and Formica sp. & Found under stone near ants. & {$[64,65]$} \\
\hline \multicolumn{4}{|l|}{ Oonopidae } \\
\hline Dysderina principalis (Keyserling) & $\begin{array}{l}\text { Labidus praedator (Smith) (publ. as Eciton } \\
\text { praedator) }\end{array}$ & Found inside nests. & {$[66]$} \\
\hline $\begin{array}{l}\text { Gamasomorpha maschwitzi } \\
\text { Wunderlich }\end{array}$ & $\begin{array}{l}\text { Leptogenys processionalis distinguenda (Emery) } \\
\text { (publ. as L. distinguenda) }\end{array}$ & $\begin{array}{l}\text { Found inside nests. Chemical } \\
\text { mimic. Phoretic. Follows } \\
\text { emigration trails of hosts. } \\
\text { Builds webs inside nest. }\end{array}$ & {$[65,67-69]$} \\
\hline $\begin{array}{l}\text { Gamasomorpha wasmanniae } \\
\text { Mello-Leitão }\end{array}$ & Eciton sp. & Found inside nests. & {$[70]$} \\
\hline $\begin{array}{l}\text { Xestaspis loricata (L. Koch) (publ. as } \\
\text { G. loricata) }\end{array}$ & Myrmecia dispar (Clark) & Found inside nests. & {$[71]$} \\
\hline \multicolumn{4}{|l|}{ Salticidae } \\
\hline Cosmophasis bitaeniata (Keyserling) & Oecophylla smaragdina (Fabricius) & $\begin{array}{l}\text { Lives inside nest. Is chemical } \\
\text { mimic of ant. Feeds on ant } \\
\text { larvae by using tactile } \\
\text { mimicry. }\end{array}$ & {$[72-76]$} \\
\hline $\begin{array}{l}\text { Phintella piatensis Barrion and } \\
\text { Litsinger }\end{array}$ & O. smaragdina & Lives in proximity to ants. & {$[77]$} \\
\hline \multicolumn{4}{|l|}{ Theridiidae } \\
\hline Eidmannella pallida (Emerton) & Atta sexdens (L.) & $\begin{array}{l}\text { Lives in old fungus chambers } \\
\text { of nest. }\end{array}$ & {$[78]$} \\
\hline
\end{tabular}

an isolated ecosystem. Arthropods symbiotic with ant hosts typically experience a stable microclimate, plentiful food (either in the form of other symbionts, the hosts themselves, or other resources brought into the colony by the hosts), and protection from their own predators and parasites [5, $68,77]$. The degree of integration into the colonies varies greatly from species with just a loose affiliation or association with the ant nests to symbionts that spend their entire lives within the ant nests and fail to thrive when removed from this habitat $[5,79]$. These symbionts can have a neutral, a positive, or a negative influence on the host colonies depending on their natural history. If the effect of the myrmecophile on the host is costly enough, there should be selection for the host to recognize and attack or remove these guests from the nest [69]. For example, the myrmecophile Masoncus pogonophilus Cushing (Linyphiidae) feeds on collembolans and other symbionts found in the colonies of the harvester ant, Pogonomyrmex badius (Latreille) [80] (Figure 2). Therefore, this spider may have a slightly negative effect on the colonies of these ants since the primary prey of the spiders, collembolans, graze fungal spores found inside the nest chambers, particularly the seed storage chambers [80], and thus keep fungal infestations low. However, populations of these spiders are so small within any given colony that their net effect on the host's success is probably negligible $[79,80]$. Some evidence suggests that hosts can recognize and will attack these symbionts, particularly those introduced from a neighboring nest $[81$, Cushing pers. obs.]. The myrmecophilic spider Gamasomorpha maschwitzi (Wunderlich) (Oonopidae) is found inside the nests and bivouacs of the army ant, Leptogenys distinguenda (Emery), where it apparently feeds on insects captured by the hosts. Therefore, this myrmecophile has a negative impact on host fitness as a kleptoparasite on the host's prey. However, as with M. pogonophilus, the abundance of spiders within any given colony is so low that its negative impact is likely negligible and these spider guests are either ignored or treated with only very low levels of aggression $[67,68]$. Sometimes spiders are even groomed by the host ants [69]. The spider Attacobius attarum (Roewer) (Corinnidae) (originally published as the clubionid Myrmecques attarum) lives with Atta sexdens (L.) where it feeds on ant larvae and pupae [82] and thus also has a negative impact on host colonies. The hosts are known to antennate the spiders but do not show any aggression towards these myrmecophiles [82].

It has been noted that certain types of ant colonies are more open to invasion by myrmecophiles than others. Characteristics of host colonies that are most open to invasion by myrmecophiles include: colonies with multiple queens (polygynous colonies), colonies with multiple nest sites (polydomous colonies, which are often also polygynous), and very large colonies [83]. These societies tend to be more "loose, flexible, and dynamic" than monogynous colonies and tend to have less social cohesion leading to increased 


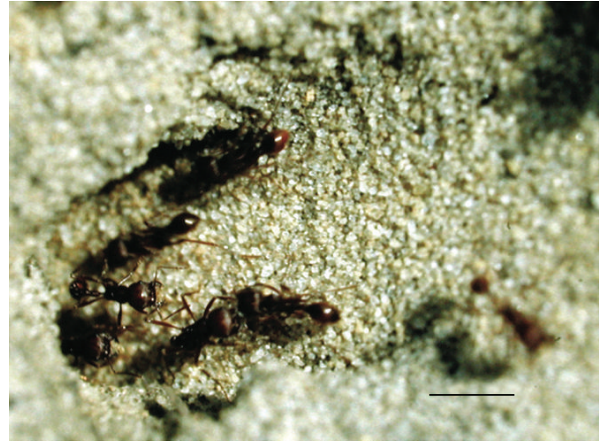

(a)

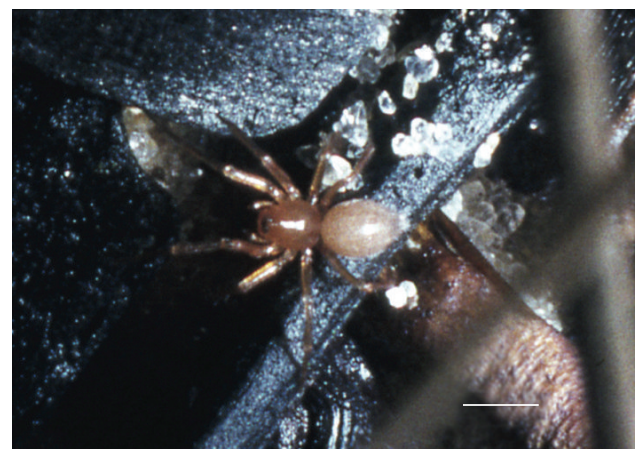

(b)

Figure 2: Myrmecophily in spiders. (a) The host ant Pogonomyrmex badius (Latreille) at the nest entrance. (b) The myrmecophilic spider, Masoncus pogonophilus Cushing on the surface, walking along the emigration trail of the host ant. Scale bar in $(\mathrm{a})=8 \mathrm{~mm}$, scale bar in $(\mathrm{b})=$ $1 \mathrm{~mm}$. Photos () author.

vulnerability to invasion by myrmecophiles [83]. In general, myrmecophile populations tend to occur in one of the following distinct patterns: (1) a myrmecophilic species is found in many colonies at certain locations throughout a host species' range but not at other locations (i.e., high infestation but low transmission), (2) a myrmecophilic species is found throughout the host's range but only within a few colonies at any given locality (i.e., low infestation but high transmission), or (3) the myrmecophile is found in only a few colonies at any one locality and not throughout the host's range (i.e., low infestation and low transmission) [83]. Population size of myrmecophiles is often quite low within a colony, but this depends on the type of myrmecophile. Spider myrmecophiles that have been studied in any depth, in general, tend to have small populations within a colony $[67,68,79]$. Intraspecific aggression between spider myrmecophiles within a colony has been reported [69] and may be one factor in keeping populations small.

\subsection{General Adaptations Facilitating Integration into Colonies.} Close integration within ant colonies seems to be more common in certain families, such as the Linyphiidae and Oonopidae [5]. These spiders have several characteristics (morphological and behavioral) that may serve as preadaptations to a symbiotic lifestyle inside ant nests [67]. For example, both families include very small spiders (typically less than $5 \mathrm{~mm}$ ); the species are often found in moist, humid microhabitats such as leaf litter, under rocks or logs, or under bark; and many species in these families (particularly oonopids) have morphological adaptations such as hard sclerotized scuta covering their abdomens that may provide some protection against attacks by host ants. Witte and colleagues point out that some species of oonopids may scavenge insect remains in the webs of other spiders [67]. All these behavioral and ecological characteristics may preadapt spiders to a myrmecophilic lifestyle within ant colonies. Smaller body sizes allow them to "sneak" inside the nests and become integrated. Protective scuta (and small sizes) may provide some protection against attacks from the hosts. A scavenger lifestyle may be considered a preadaptation to stealing food (insects or ant brood) from workers. The constant temperature and humidity of an underground ant nest may be an attractive environment to species otherwise restricted to similar temperature and humidity regimes.

Once integrated into colonies, spider myrmecophiles certainly have evolved dramatic host-specific adaptations allowing them to become even more integrated into various aspects of the host's life cycle. These adaptations, in turn, place severe constraints on the geographical distribution of these inquilines or ant guests; the symbionts are restricted to the range of that host species [83]. This may explain why such inquilines are very localized or rare and may be subject to frequent extinctions [83]. Adaptations common to myrmecophiles include evasive devices such as behaviors, morphological structures, or chemical signals used to appease hosts or to mimic hosts; protective morphological structures such as sclerotized cuticular "shields" or plates; mechanisms to communicate with hosts via chemical cues, tactile cues, or even auditory cues [83].

3.4. Chemical Mimicry. Among spider myrmecophiles, besides the preadaptations mentioned above, many have evolved the capacity to absorb, biosynthesize, or otherwise mimic the host ant's cuticular hydrocarbon colony odor. To survive inside the host colony, the guest must be considered a nest mate by the hosts and should, therefore, have somehow acquired the chemical odor of the hosts via either biosynthesis of the key compounds or by passively acquiring the chemical cues [84]. Thus far, no research has definitively documented glandular secretions that spider myrmecophiles might use to biosynthesize the compounds. If such glands are documented, then it is likely that the association between the host and the myrmecophile is an ancient association and the myrmecophile and host coevolved [85, 86]. However, biosynthesis may evolve rapidly in myrmecophile populations if the compounds biosynthesized can be easily manufactured by co-opting an already existing chemical pathway or if the guest can re-purpose an already existing compound [86].

The chemical signature of ant colonies may change over time [2]. Thus intruders (guests) into colonies must be able 
to update their profiles constantly in order to avoid detection and attack. If the myrmecophile's chemical profile does not match the host's closely enough then it will become more difficult for the guest to approach the host in order to update its profile, making social integration into the colonies a "well-balanced and potentially fragile system" [69]. Myrmecophiles can acquire colony odors by rubbing against the host ants, associating with nest materials, or by eating the ant's brood (larvae or pupae) [84]. All these mechanisms are seen in spider myrmecophiles. It may be that these myrmecophiles do not need to acquire an exact chemical match to the host's hydrocarbon profile, but need only one or two key constituents that are biologically most important in nest recognition and acceptance by the hosts [86].

For example, the oonopid, G. maschwitzi, found with the army ant, $L$. distinguenda, has a cuticular hydrocarbon profile that includes only compounds also seen in the host ant's profile but not all the compounds seen in the host's profile [69]. These spiders crawl on top of workers, moving their legs actively over the cuticle of the host, perhaps as an adaptation to acquire the host's chemical odor $[68,69,78]$. The hydrocarbon profile of the myrmecophilic spider matches that of the host's to a high degree; however, colony-specific matching was not evident [69]. Nevertheless, ants of $L$. distinguenda from different colonies did not show high levels of intercolony aggression; therefore, it may not matter that the myrmecophile's profile lacks these colony-specific compounds but just generally matches the gestalt odor of the species (i.e., has key chemical constituents that identify it as an ant and a member of the same species) [68, 69]. Research has also demonstrated that the phoresy displayed by G. maschwitzi may also function as a behavioral mechanism for the spider to acquire food (ant larvae, pupae, or insects being carried by the workers) via kleptoparasitism [68]. The spider riding on the back of the ant snatches the food item directly from the host's mandibles. In fact, these spiders have not been observed to hunt prey on their own [67] so this kleptoparasitic lifestyle may be another example of extreme adaptation related to their symbiotic life with these ants.

The salticid Cosmophasis bitaeniata (Keyserling) lives inside the colonies of the weaver ant, Oecophylla smaragdina (Fabricius), where it feeds on the larvae of the host ant [7275]. The spider is more often found in and around older nests that have lots of larvae [72]. The spider touches the antennae and head of minor workers with its front legs, stimulating the workers to release the larva that the worker is carrying [72]. The spider otherwise avoids direct contact with the worker ants $[72,75]$. The spider is a chemical mimic of the host [73-76]. It has been shown that the spider acquires the colony specific hydrocarbon profile by handling and eating the ant larvae $[74,76]$. The hydrocarbon profile of the spider is colony specific but does not match the profile of the major workers [75]. Larvae from different colonies do not elicit aggressive responses from the host; thus spiders that mimic the hydrocarbon profile of the larvae rather than the workers may be more easily accepted by both their own hosts as well as those of neighboring colonies [76].

The spider Attacobius attarum that lives inside the nests of the leaf cutter ant, Atta sexdens (L.) rides on the dorsa of workers and alates $[78,82,87]$. The spiders may disperse to new colonies via the alates [78, 82, 87]. Attacobius attarum, like G. maschwitzi and C. bitaeniata, is a kleptoparasite; the spider feeds on ant larvae and pupae and can steal the brood directly from the mandibles of workers [82]. The ants antennate the spiders and the spiders reciprocate by "antennating" the ants with their front legs, possibly providing mimetic tactile cues [82]. No aggression towards these kleptoparasites has been reported [82].

The theridiid spider, Eidmannella pallida (Emerton) (published as Eidmannella attae), also lives with $A$. sexdens where it is found in unused fungus chambers that the ants use to store refuse and dead ants [78]. Likewise, the linyphiid, M. pogonophilus, lives in seed chambers and empty chambers of the seed harvester ant, $P$. badius $[79,80]$. Both these spider myrmecophiles may acquire host colony odor passively via the nest materials. Neither has been reported as phoretic, as kleptoparasitic, or as a predator of the hosts or their brood. Thus passive integration and acquisition of colony odor is likely for these symbionts.

3.5. Ability to Follow Chemical Cues of the Hosts. Cosmophasis bitaeniata can distinguish between nestmate and non-nestmate major workers and shows less tendency to try and escape when confined with nestmates, demonstrating that these myrmecophiles are not only chemical mimics but are also able to interpret chemical cues provided by the hosts [74]. Data suggests that the ability to interpret chemical signals of the hosts may be a general characteristic of spider myrmecophiles that are closely integrated into ant colonies. Research on M. pogonophilus and G. maschwitzi showed that spiders are able to follow trail pheromones laid by the ants $[67,68,79,80]$. In controlled tests, Witte et al. found that G. maschwitzi is sensitive to high concentrations of naturally laid ant trail pheromones [67]. I found M. pogonophilus in the emigration trails of $P$. badius when the hosts emigrated to new nest sites [79, 80] (Figure 2(b)).

Spider myrmecophiles may use ant trail pheromones as a means of dispersing to new colonies. In a given habitat, it is not uncommon to find spider myrmecophiles in all or nearly all the nests of a given host, even if the host is not polygynous or polydomous $[68,79]$. Thus in at least these instances, dispersal to new colonies must be occurring. Only one study has attempted to examine the population structure of a myrmecophilic spider, M. pogonophilus, which was found in nearly all colonies of $P$. badius in a given habitat (i.e., 10 colonies out of 12 that were excavated) [79]. Pogonomyrmex badius colonies are established by single inseminated queens [88] that can live for at least 15 years [89]. I hypothesized that spider populations might be considered metapopulations [90], made up of isolated demes, or local populations, with very low per-generation migration between populations resulting in low genetic diversity between individuals within populations (i.e., myrmecophiles within an ant nest) and higher genetic heterogeneity between populations (i.e., between populations of spiders found in different colonies) due to genetic drift [79]. Instead, I found that genetic diversity among individual spiders within populations (within a 
colony) was greater than the genetic diversity between populations from neighboring ant nests suggesting that spiders do disperse to new nests frequently enough to maintain high intra-population differentiation and low inter-population differentiation [79]. Although tests of the spiders' ability to follow trail pheromones (naturally laid and artificial trails) were inconclusive, I further hypothesized that spiders were able to locate new nests by following trail pheromones. They were found to emigrate with their hosts to new nest sites (see above), thus they may, during emigration, get "side-tracked" onto the foraging trail of a neighboring P. badius colony [79].

3.6. Life Cycle of Spider Myrmecophiles. Very little is known about the life cycle of any spider myrmecophile. Even for one of the best studied species, G. maschwitzi, no spiderlings have ever been detected in the emigration trails nor inside the nests [67, and Volker Witte, pers. communication]. Masoncus pogonophilus builds prey capture webs inside nest chambers and females deposit small silken egg sacs each containing up to seven eggs in depressions in the walls of the chambers [80]. The salticid, C. bitaeniata also deposits its egg sacs within the nest chambers of O. smaragdina [72]. A G. maschwitzi female was collected with one large egg in the abdomen and another with five smaller eggs [67]. Both M. pogonophilus and $C$. bitaeniata have female biased sex ratios [72, 80].

3.7. Future Directions. A great deal more research needs to be done to understand the basic biology of spider myrmecophiles. Questions and directions for future research include the following.

(i) How closely integrated are spider myrmecophiles with their host ants?

(ii) How do these spiders reproduce inside the ant colonies or does reproduction occur outside the nests?

(iii) How do they disperse to colonize other nests?

(iv) Is chemical integration a widespread phenomenon among spider myrmecophiles?

(v) Can any spider symbiont biosynthesize chemical compounds that act to appease or mimic the hosts?

(vi) Are spider myrmecophiles generally able to interpret the chemical signals of their hosts?

(vii) Is there evidence of a co-evolutionary relationship between symbionts and hosts?

(viii) How closely related are spider myrmecophiles within a colony and do these patterns of relatedness explain the female-biased sex ratios seen in some species?

\section{Spider Myrmecophagy}

4.1. Species Records. Spiders, like other arthropod predators, generally avoid preying upon ants. However, ants have been documented as part of the diet for well over 100 species of spiders (Table 1). Fossil evidence of spider myrmecophagy dates back 30-50 mya in Baltic amber specimens including one containing an inclusion of spider silk with an ant that had been fed upon as well as another showing a spider with an ant in its chelicerae [91]. Myrmecophagic spiders exist on a continuum from euryphagous to stenophagous predators [92]. Huseynov et al. [92] propose five categories of spider myrmecophages: (1) non-acceptors of ants (the majority of spider species); (2) reluctant acceptors that do prey on ants but prefer other prey; (3) indifferent acceptors that feed indiscriminately on ants and other prey; (4) facultative ant choosers that prefer ants to other prey; (5) obligatory ant choosers that feed exclusively on ants (unless severely food deprived). In Table 2 , the various spider myrmecophages that have been documented from the literature are categorized as (R) Reluctant acceptors, (I) Indifferent acceptors, (F) Facultative ant choosers, or $(\mathrm{O})$ Obligatory ant choosers based upon information about their biology provided in the literature. If researchers have only documented that the particular species eats ants but provide no other information about the hunting behavior or prey preference of the spiders, the species is categorized as (Unk) Unknown. However, these spiders are likely to turn out to be either reluctant or indifferent acceptors of ants in the diet. Details of the predatory biology of spider myrmecophages are also included in the table.

4.2. Evolutionary Costs and Benefits of Myrmecophagy. Spider myrmecophagy is a high risk hunting strategy. Risks for myrmecophages include being attacked by the prey, living in close proximity to dangerous prey, being attacked when mating, having the prey attack and destroy one's eggs if nesting and oviposition occur close to the ant nests $[58,143,175]$. However, a spider that evolves strategies for overcoming an ant's defenses and aggression faces relatively little competition for a nearly unlimited food resource $[114,143]$ (Figure 3(a)).

One study demonstrated that myrmecophagic spiders may actually derive protection against attacks from their own prey: when myrmecophagic, myrmecophilic, myrmecomorphic, and non-ant associating salticids were trapped with ants, the myrmecophagic spiders showed the highest survival rate followed by the myrmecomorphs and myrmecophiles, suggesting that ant associates may signal the ants in such a way that the ants show little aggression towards these spiders [176]. Thus not only are myrmecophagic spiders obtaining a nutrient rich, unlimited food supply through their specialized diet, but they may also be deriving protection from the ants, just as myrmecophilic and myrmecomorphic spiders do.

Although it has not been suggested that spider myrmecophages are chemical mimics of ants, as has been demonstrated for spider myrmecophiles, there is some evidence that certain species of myrmecophages may either be releasing chemical compounds that appease their potential prey or may be able to "read" chemical cues released by ants. For example, Lubin suggested that the thomisid, Tmarus stoltzmanni Keyserling, may use its 1st and 2nd pairs of legs to detect chemical or tactile cues from the ants [148]. Habronestes bradleyi (O. P.-Cambridge) (Zodariidae) waves its front legs around when hunting and, when the legs are amputated, the spider has a difficult time locating ant prey 
TABle 2: Spider myrmecophages. ${ }^{*}$ Categories (defined in text) include R: Reluctant myrmecophage; I: Indifferent acceptor; F: Facultative ant predator; O: Obligatory ant predator; Unk: cannot be determined from information about their biology presented in the literature (these are most likely R or I myrmecophages). Spider taxonomy according to Platnick [63]; ant taxonomy according to http://antbase.org/.

\begin{tabular}{|c|c|c|c|}
\hline Spider myrmecophage & $\begin{array}{c}\text { Category of } \\
\text { myrmecophage }^{*}\end{array}$ & Notes on biology & References \\
\hline \multicolumn{4}{|l|}{ Araneidae } \\
\hline Metepeira gosoga Chamberlin and Ivie & Unk & $\begin{array}{l}\text { Author suggests that spiders may feed on ants found } \\
\text { only on cholla where spider is also found. }\end{array}$ & {$[93]$} \\
\hline Metepeira sp. & Unk & Reported feeding on Crematogaster opuntiae Buren. & [93] \\
\hline \multicolumn{4}{|l|}{ Deinopidae } \\
\hline Deinopis sp. & Probably I & Throws web over ants passing below. & {$[94]$} \\
\hline \multicolumn{4}{|l|}{ Eresidae } \\
\hline Seothyra sp. & $\mathrm{F}$ & $\begin{array}{l}\text { Lives in silk lined burrows. Mouth of burrow covered } \\
\text { by prey capture web. Captures mostly ants. Male spider } \\
\text { runs on ground during day and is myrmecomorph and } \\
\text { behavioral mimic of Camponotus sp. and mutillid } \\
\text { wasps (dimorphic mimicry). }\end{array}$ & {$[95]$} \\
\hline \multicolumn{4}{|l|}{ Gnaphosidae } \\
\hline Callilepis nocturna (L.) & May be F & $\begin{array}{l}\text { Feeds on Formica spp. and Lasius spp. Actively searches } \\
\text { for ants and may enter nests to hunt workers. } \\
\text { Approaches ant and bites on base of antenna. Antennae } \\
\text { seem to act as stimulus to trigger attack. }\end{array}$ & {$[96-98]$} \\
\hline \multicolumn{4}{|l|}{ Linyphiidae } \\
\hline Frontinella communis (Hentz) & I & Occasionally preys on ants. & {$[99]$} \\
\hline \multicolumn{4}{|l|}{ Oecobiidae } \\
\hline Oecobius annulipes Lucas & $\mathrm{O}$ & $\begin{array}{l}\text { Main food is Plagiolepis pygmaea (Latreille) but other } \\
\text { ants (e.g., Lasius flavus (Fabricius)) accepted in lab. } \\
\text { Bites at base of antenna. Swaths ant in silk and encircles } \\
\text { it. Sometimes uses last pair of legs as well as spinnerets } \\
\text { to direct silk over prey. Reduced chelicerae and } \\
\text { enlarged gnathocoxae may be adaptations to } \\
\text { myrmecophagic lifestyle. }\end{array}$ & {$[100]$} \\
\hline O. cellariorum (Dugès) & $\mathrm{O}$ & $\begin{array}{l}\text { Feeds on Plagiolepis pygmaea (Latreille). Bites at base of } \\
\text { antenna. }\end{array}$ & {$[100]$} \\
\hline O. templi O. P.-Cambridge & $\mathrm{O}$ & & {$[100]$} \\
\hline \multicolumn{4}{|l|}{ Oonopidae } \\
\hline Triaeris stenaspis Simon (publ. as T. patellaris) & Unk & Reported attacking Cyphomyrmex costatus Mann. & {$[101]$} \\
\hline \multicolumn{4}{|l|}{ Oxyopidae } \\
\hline Oxyopes apollo Brady & Unk & Eats ants. & {$[102]$} \\
\hline O. globifer Simon & $\mathrm{I} / \mathrm{F}$ & Ants constitute large \% of prey. & {$[99,102]$} \\
\hline O. licenti Schenkel & Unk & Eats ants. & [102] \\
\hline O. salticus Hentz & Unk & Eats ants. & {$[102]$} \\
\hline O. scalaris Hentz & I & Occasionally eats ants. & {$[99,102]$} \\
\hline O. sertatus L. Koch & Unk & Eats ants. & {$[102]$} \\
\hline Peucetia viridans (Hentz) & Unk & Eats ants. & {$[103]$} \\
\hline \multicolumn{4}{|l|}{ Pholcidae } \\
\hline $\begin{array}{l}\text { Crossopriza lyoni (Blackwall) (publ. as } \\
\text { Crossopriza stridulans) }\end{array}$ & Unk & Feeds on fire ants, Solenopsis invicta Buren. & {$[104]$} \\
\hline \multicolumn{4}{|l|}{ Salticidae } \\
\hline $\begin{array}{l}\text { Aelurillus aeruginosus (Simon), A. cognatus } \\
\text { (O. P.-Cambridge), and A. kochi Roewer }\end{array}$ & $\mathrm{F}$ & $\begin{array}{l}\text { Prefer ants over other prey. Innately recognize ants even } \\
\text { if ants are not moving. Attack from front unless ant is } \\
\text { passing (then switch to rear attack). Use different } \\
\text { hunting behavior for ants than for other prey. If } \\
\text { hungry, show no preference for ants over other prey. }\end{array}$ & {$[105]$} \\
\hline
\end{tabular}


Table 2: Continued.

\begin{tabular}{|c|c|c|c|}
\hline Spider myrmecophage & $\begin{array}{c}\text { Category of } \\
\text { myrmecophage* }^{*}\end{array}$ & Notes on biology & References \\
\hline Aelurillus m-nigrum Kulczyński & $\mathrm{F}$ & $\begin{array}{l}\text { Prefers ants over other prey; } 85 \% \text { of diet in field } \\
\text { consists of ants. Uses different hunting behaviors for } \\
\text { ants than for other prey: lunges, attacks from front, } \\
\text { bites, releases, bites again. }\end{array}$ & {$[92]$} \\
\hline Aelurillus spp. & $\mathrm{F}$ & $\begin{array}{l}\text { Species in genus prefer ants over other prey. Use } \\
\text { different hunting behaviors for ants than for other prey. }\end{array}$ & {$[106]$} \\
\hline $\begin{array}{l}\text { Anasaitis canosa (Walckenaer) (publ. as } \\
\text { Corythalia canosa or as Stoidis aurata) }\end{array}$ & $\mathrm{F}$ & $\begin{array}{l}\text { Prefers ants over other prey. Uses different hunting } \\
\text { behaviors for ants than for other prey: attacks from } \\
\text { front, holds forelegs away from struggling ant. Also } \\
\text { stilts body off ground. }\end{array}$ & {$[107,108]$} \\
\hline Anasaitis spp. & $\mathrm{F}$ & $\begin{array}{l}\text { Species in genus prefer ants over other prey. Use } \\
\text { different hunting behaviors for ants than for other prey. }\end{array}$ & {$[106]$} \\
\hline Chalcotropis spp. & $\mathrm{F}$ & $\begin{array}{l}\text { Use different hunting behaviors for ants than for other } \\
\text { prey: some attack from rear, some head-on, then lunge, } \\
\text { bite, release, and wait. }\end{array}$ & {$[106,109]$} \\
\hline Chrysilla lauta Thorell & $\mathrm{F}$ & $\begin{array}{l}\text { Prefers ants. Uses different hunting behaviors for ants } \\
\text { than for other prey: attacks from rear, bites gaster (not } \\
\text { appendages), retreats and waits, may lunge and strike } \\
\text { several times. When ant quiescent, spider approaches, } \\
\text { bites again, and carries it away. }\end{array}$ & {$[110]$} \\
\hline Chrysilla spp. & $\mathrm{F}$ & $\begin{array}{l}\text { Species in genus prefer ants over other prey. Use } \\
\text { different hunting behaviors for ants than for other prey. }\end{array}$ & {$[106]$} \\
\hline Cosmophasis sp. & Unk & Feeds on ants and is myrmecomorph. & {$[59]$} \\
\hline Euophyrs spp. & $\mathrm{F}$ & $\begin{array}{l}\text { Use different hunting behaviors for ants than for other } \\
\text { prey: some attack from rear, some attack head-on, then } \\
\text { lunge, bite, release, and wait. }\end{array}$ & {$[106]$} \\
\hline Evarcha albaria (L. Koch) & $\mathrm{I} / \mathrm{F}$ & $\begin{array}{l}\text { Robs ants of their prey and of their brood (eggs and } \\
\text { larvae) that workers carry (kleptoparasites). }\end{array}$ & {$[111]$} \\
\hline Habrocestum pulex (Hentz) & $\begin{array}{l}\text { Some F } \\
\text { Some I }\end{array}$ & $\begin{array}{l}\text { Some individuals prefer ants over other prey; some } \\
\text { prefer other prey over ants. Myrmecophagic individuals } \\
\text { use different behaviors for ants than for other prey: } \\
\text { lunge or leap onto petiole or thorax, bite, release, repeat } \\
\text { (up to } 6 \text { times). Keep front legs off ground away from } \\
\text { ant. Reported preying on Crematogaster spp. }\end{array}$ & {$[112-114]$} \\
\hline Habrocestum spp. & $\mathrm{F}$ & $\begin{array}{l}\text { Species in genus prefer ants over other prey. Use } \\
\text { different hunting behaviors for ants than other prey. }\end{array}$ & {$[106]$} \\
\hline Hasarius adansoni (Audouin) & Probably I & Will feed on ants. & {$[115]$} \\
\hline $\begin{array}{l}\text { Hentzia palmarum (Hentz) (publ. as Eris } \\
\text { marginata) }\end{array}$ & Unk & Reported feeding on workers of Myrmica sp. & {$[113]$} \\
\hline Icius sp. & Unk & Reported feeding on small brown ants. & {$[113]$} \\
\hline $\begin{array}{l}\text { Menemerus fulvus (L. Koch) (publ. as } \\
\text { Menemerus confuses) }\end{array}$ & $\mathrm{I} / \mathrm{F}$ & $\begin{array}{l}\text { Robs ants of their prey and of their brood (eggs and } \\
\text { larvae) that workers carry (kleptoparasites). }\end{array}$ & {$[111]$} \\
\hline Myrmarachne foenisex Simon & $\mathrm{F}$ & $\begin{array}{l}\text { Regularly feeds on weaver ant (Oecophylla) larvae. Also } \\
\text { mimics weaver ants. }\end{array}$ & {$[59]$} \\
\hline $\begin{array}{l}\text { Natta horizontalis Karsch (publ. as Cyllobelus } \\
\text { rufopictus) }\end{array}$ & $\mathrm{F}$ & $\begin{array}{l}\text { Prefer ants. Uses different hunting behaviors for ants } \\
\text { than for other prey: attacks from rear, bites gaster (not } \\
\text { appendages), retreats, and waits, may lunge and strike } \\
\text { several times. When ant quiescent, spider approaches, } \\
\text { bites again, and carries it away. }\end{array}$ & {$[110]$} \\
\hline Natta spp. & $\mathrm{F}$ & $\begin{array}{l}\text { Species in genus generally prefer ants. Use different } \\
\text { hunting behaviors for ants than for other prey: attack } \\
\text { from rear, bite gaster (not appendages), retreat and } \\
\text { wait, may lunge and strike several times. When ant } \\
\text { quiescent, spider approaches, bites again, and carries it } \\
\text { away. }\end{array}$ & {$[106,110]$} \\
\hline
\end{tabular}


Table 2: Continued.

\begin{tabular}{|c|c|c|c|}
\hline Spider myrmecophage & $\begin{array}{c}\text { Category of } \\
\text { myrmecophage }^{*}\end{array}$ & Notes on biology & References \\
\hline Phidippus johnsoni (Peckham and Peckham) & I & Occasionally eats ants. & {$[99,116]$} \\
\hline Plexippus setipes Karsch & $\mathrm{I} / \mathrm{F}$ & $\begin{array}{l}\text { Robs ants of their prey and of their brood (eggs and } \\
\text { larvae) that workers carry (kleptoparasites). }\end{array}$ & {$[111]$} \\
\hline Siler cupreus Simon (publ. as Silerella vittata) & $\mathrm{F} / \mathrm{O}$ & $\begin{array}{l}\text { Eats ants. Spider population increases in areas infested } \\
\text { with Argentine ants, Linepithema humile (Mayr). Also } \\
\text { robs worker ants of brood including eggs, larvae, and } \\
\text { pupae being carried by workers (kleptoparasitism). }\end{array}$ & {$[117-120]$} \\
\hline Siler semiglaucus (Simon) & $\mathrm{F}$ & $\begin{array}{l}\text { Prefer ants. Uses different hunting behaviors for ants } \\
\text { than for other prey; bites gaster (not appendages), } \\
\text { retreats and waits, may lunge and strike several times. } \\
\text { When ant quiescent, spider approaches, bites again, and } \\
\text { carries it away. }\end{array}$ & {$[110]$} \\
\hline Siler spp. & $\mathrm{F}$ & $\begin{array}{l}\text { Use different hunting behaviors for ants than for other } \\
\text { prey: some attack from rear, some from head-on, lunge, } \\
\text { bite, release and wait. }\end{array}$ & {$[106,109]$} \\
\hline Tutelina formicaria (Emerton) & $\mathrm{F}$ & Also myrmecomorph. Preys on red and black ants. & {$[121]$} \\
\hline Tutelina similis (Banks) & $\mathrm{F}$ & $\begin{array}{l}\text { Preys primarily on ants and is also a myrmecomorph. } \\
\text { Uses different hunting behaviors for ants than for other } \\
\text { prey: bites quickly, releases, retreats, carries paralyzed } \\
\text { prey to safe area. }\end{array}$ & {$[99,113]$} \\
\hline Tutelina spp. & $\mathrm{F}$ & $\begin{array}{l}\text { Other species of Tutelina found on mound of } \\
\text { Pogonomyrmex salinus Olsen (publ. as P. owyheei) } \\
\text { feeding on worker ants. }\end{array}$ & {$[113]$} \\
\hline Xenocytaea spp. & $\mathrm{F}$ & $\begin{array}{l}\text { Species in genus prefer ants over other prey. Use } \\
\text { different hunting behaviors for ants than other prey. }\end{array}$ & {$[106]$} \\
\hline $\begin{array}{l}\text { Zenodorus durvillei (Walckenaer), Z. } \\
\text { metallescens (L. Koch), and Z. orbiculatus } \\
\text { (Keyserling) }\end{array}$ & $\mathrm{F}$ & $\begin{array}{l}\text { Prefer ants over other prey. Feed on ants caught in } \\
\text { other spider's webs-but only if spiders can approach } \\
\text { safely without getting caught. Ambush ants; hang } \\
\text { upside down and lunge at ant while releasing dragline. } \\
\text { Repeatedly bite larger ants. Do not hold onto injured } \\
\text { ant. }\end{array}$ & {$[106,108]$} \\
\hline Zenodorus spp. & $\mathrm{F}$ & $\begin{array}{l}\text { Species in genus prefer ants over other prey. Use } \\
\text { different hunting behaviors for ants than other prey. }\end{array}$ & {$[106]$} \\
\hline \multicolumn{4}{|l|}{ Scytodidae } \\
\hline Scytodes sp. & Unk & Feeds on fire ants, Solenopsis invicta Buren. & {$[104]$} \\
\hline \multicolumn{4}{|l|}{ Theridiidae } \\
\hline Achaearanea spp. & Unk & $\begin{array}{l}\text { Feed on "carpenter ants." Ants become entangled in } \\
\text { gum footed sticky thread attached to substrate. } \\
\text { Movement of ant causes thread to snap and ant is lifted } \\
\text { off ground. }\end{array}$ & {$[93]$} \\
\hline Argyrodes sp. & Unk & Reported feeding on Pogonomyrmex rugosus Emery. & {$[93]$} \\
\hline $\begin{array}{l}\text { Asagena fulva (Keyserling) (publ. as Steatoda } \\
\text { fulva) and A. pulcher (Keyserling) (publ. as S. } \\
\text { pulcher) }\end{array}$ & Unk & $\begin{array}{l}\text { Feed on Pogonomyrmex badius (Latreille) and } P \text {. } \\
\text { subnitidus Emery. When ant workers captured in webs, } \\
\text { major workers (patrollers) may attempt to free them } \\
\text { but become caught in webs themselves. }\end{array}$ & {$[93,122]$} \\
\hline $\begin{array}{l}\text { Cryptachaea riparia (Blackwall) (publ. as } \\
\text { Theridion saxatile and as Acaeoraneae riparia) }\end{array}$ & $\mathrm{F}$ & $\begin{array}{l}\text { Captures ants with above-ground web that has sticky } \\
\text { threads attached to substrate. Webs built in areas of } \\
\text { high ant activity or traffic. Greater than } 88 \% \text { of diet } \\
\text { made up of ants (mostly Formica spp.). Ant gets tangled } \\
\text { in sticky silk, struggling causes line to snap, ant is } \\
\text { suspended, spider responds to vibrations, bites ant } \\
\text { several times in legs and antennae while wrapping in } \\
\text { silk, cuts paralyzed ant, and carries it to sand-covered } \\
\text { tube retreat. }\end{array}$ & {$[123,124]$} \\
\hline Dipoena punctisparsa Yaginuma & Unk & Feeds on small ants in genus Lasius. & {$[125]$} \\
\hline
\end{tabular}


Table 2: Continued.

\begin{tabular}{|c|c|c|c|}
\hline Spider myrmecophage & $\begin{array}{c}\text { Category of } \\
\text { myrmecophage* }^{\text {Carmecos }}\end{array}$ & Notes on biology & References \\
\hline $\begin{array}{l}\text { Enoplognatha ovata (Clerck) (publ. as } \\
\text { Theridion lineatum or T. lineamentum) }\end{array}$ & Unk & $\begin{array}{l}\text { Feeds on Pogonomyrmex barbatus (Smith). Builds webs } \\
\text { in grass near colony. Ants crawling up into grass or } \\
\text { passing below get entangled. }\end{array}$ & {$[126]$} \\
\hline Euryopis californica Banks & $\mathrm{I} / \mathrm{F}$ & Reported feeding on Pogonomyrmex rugosus Emery. & [93] \\
\hline Euryopis coki Levi & $\mathrm{I} / \mathrm{F}$ & $\begin{array}{l}\text { Preys on Pogonomyrmex salinus Olsen (publ. as } P \text {. } \\
\text { owyheei). Spider captures ant on the mound by } \\
\text { trapping ant against ground with sticky silk. Bites on } \\
\text { leg. Ant swings off ground on thread. When paralyzed, } \\
\text { spider drags it away using a web sling attached to the } \\
\text { ant and to the spinnerets. }\end{array}$ & [127] \\
\hline $\begin{array}{l}\text { Euryopis episinoides (Walckenaer) (publ. as E. } \\
\text { acuminata) }\end{array}$ & $\mathrm{I} / \mathrm{F}$ & $\begin{array}{l}\text { Feeds on ants. Attacks Crematogaster ants and } \\
\text { transports each attached to spinnerets. }\end{array}$ & {$[128]$} \\
\hline Euryopis formosa Banks & $\mathrm{I} / \mathrm{F}$ & $\begin{array}{l}\text { Captures and carries workers of Pogonomyrmex salinus } \\
\text { Olsen. Carries ant across ground. One attack described: } \\
\text { spider bit gaster, released ant, moved to front and } \\
\text { waited, reapproached paralyzed ant, climbed onto ant } \\
\text { and began dragging across ant nest using web sling. }\end{array}$ & [129] \\
\hline Euryopis funebris (Hentz) & $\mathrm{F} / \mathrm{O}$ & $\begin{array}{l}\text { Reported feeding on Camponotus castaneus (Latreille). } \\
\text { Throws adhesive silk over ant passing by on tree trunk } \\
\text { and fastens it to tree. Encircles ant, throwing silk. Bites } \\
\text { leg. Cuts paralyzed ant free and carries it to crack or } \\
\text { crevice or drops on line to feed. }\end{array}$ & {$[130,131]$} \\
\hline Euryopis scriptipes Banks & $\mathrm{I} / \mathrm{F}$ & Feeds on ants. & {$[132]$} \\
\hline Euryopis texana Banks & $\mathrm{I} / \mathrm{F}$ & $\begin{array}{l}\text { Female reported preying upon moving line of small } \\
\text { ants. }\end{array}$ & {$[133]$} \\
\hline Other Euryopis spp. & $\mathrm{I} / \mathrm{F}$ & $\begin{array}{l}\text { Prey on ants. Throw adhesive silk over ants and fasten } \\
\text { to trees. }\end{array}$ & {$[131-133]$} \\
\hline Latrodectus corallinus Abalos & Unk & & {$[93,134]$} \\
\hline Latrodectus hesperus Chamberlin and Ivie & Probably I & $\begin{array}{l}\text { Feeds on Pogonomyrmex rugosus Emery. Builds web on } \\
\text { colony mound over foraging trail. Spider throws silk on } \\
\text { ant that gets caught in gum threads. Spider approaches } \\
\text { ant from above, bites posterior femur, retreats, returns } \\
\text { after ant paralyzed, and pulls ant to retreat or to hidden } \\
\text { part of web. Also feeds on other species of ants. }\end{array}$ & {$[93]$} \\
\hline Latrodectus mactans (Fabricius) & $\mathrm{I} / \mathrm{F}$ & $\begin{array}{l}75 \% \text { of prey in cotton fields in Texas made up of fire } \\
\text { ants, Solenopsis invicta Buren. Also reported feeding on } \\
\text { Pogonomyrmex badius (Latreille) and P. barbatus. }\end{array}$ & $\begin{array}{l}{[89,126,} \\
135]\end{array}$ \\
\hline Latrodectus mirabilis (Holmberg) & Unk & $\begin{array}{l}\text { Feeds on Acromyrmex spp. and Camponotus spp. Builds } \\
\text { webs over colony entrances. }\end{array}$ & {$[93,134]$} \\
\hline Latrodectus pallidus O. P.-Cambridge & $\mathrm{F}$ & $\begin{array}{l}\text { Primary prey are ants. Feeds on Monomorium semirufus } \\
\text { (nomen dubium, but probably Messor semirufus } \\
\text { (André)). Females build webs over foraging trails. } \\
\text { Capture ants from above with trip line attached to } \\
\text { substrate and pull prey into retreat. Spiders can also } \\
\text { descend to ground and catch ants running on trails. }\end{array}$ & {$[136-138]$} \\
\hline L. quartus Abalos & Unk & $\begin{array}{l}\text { Feeds on Acromyrmex spp. and Camponotus spp. Builds } \\
\text { webs over colony entrances. }\end{array}$ & {$[93,134]$} \\
\hline Latrodectus revivensis Shulov & Unk & Remains of Messor sp. found in webs. & {$[136]$} \\
\hline Latrodectus tredecimguttatus (Rossi) & Unk & Remains of Messor sp. found in webs. & {$[136,137]$} \\
\hline Latrodectus spp. & Unk & $\begin{array}{l}\text { Members of genus may generally be myrmecophages. } \\
\text { Reported feeding on Monomorium sp. and Messor } \\
\text { semirufus (André). }\end{array}$ & {$[136-138]$} \\
\hline $\begin{array}{l}\text { Parasteatoda tepidariorum (C. L. Koch) (publ. } \\
\text { as Achaearanea tepidariorum) }\end{array}$ & Unk & Feeds on fire ants, Solenopsis invicta Buren. & {$[107]$} \\
\hline
\end{tabular}


Table 2: Continued.

\begin{tabular}{|c|c|c|c|}
\hline Spider myrmecophage & $\begin{array}{c}\text { Category of } \\
\text { myrmecophage* }^{*}\end{array}$ & Notes on biology & References \\
\hline $\begin{array}{l}\text { Phycosoma mustelinum (Simon) (publ. as } \\
\text { Dipoena mustelina) }\end{array}$ & Unk & Captures various species of ants of wide range of sizes. & {$[125]$} \\
\hline Steatoda albomaculata (De Geer) & I & Feeds on ants; ant remains found in webs. & {$[139]$} \\
\hline Steatoda fulva (Keyserling) & $\mathrm{I} / \mathrm{F}$ & $\begin{array}{l}\text { Reported building webs near nest entrance of colonies } \\
\text { of Pogonomyrmex badius (Latreille). }\end{array}$ & {$[122]$} \\
\hline S. triangulosa (Walckenaer) & I & Feeds on fire ants, Solenopsis invicta Buren. & {$[104]$} \\
\hline $\begin{array}{l}\text { Yaginumena castrata (Bösenberg and Strand) } \\
\text { (publ. as Dipoena castrata) }\end{array}$ & Unk & $\begin{array}{l}\text { Mostly feeds upon Camponotus sp. and Lasius sp. and } \\
\text { most individual spiders feed upon single type of prey. } \\
\text { The larger the spider, the larger the ant it can attack. }\end{array}$ & {$[125]$} \\
\hline \multicolumn{4}{|l|}{ Thomisidae } \\
\hline Amyciaea albomaculata (O. P.-Cambridge) & $\mathrm{O}$ & $\begin{array}{l}\text { Myrmecomorph of Oecophylla smaragdina (Fabricius) } \\
\text { (publ. as O. virescens). Adult spiders with eye spots on } \\
\text { abdomen. Juvs. yellow and mimic other species of } \\
\text { yellow ants (transformational mimics). Spider waits } \\
\text { near foraging trail of ant, attacks from behind, bites } \\
\text { back of body, drags paralyzed ant to edge of vegetation, } \\
\text { drops down to feed. }\end{array}$ & {$[140]$} \\
\hline $\begin{array}{l}\text { Aphantochilus rogersi O. P.-Cambridge (publ. } \\
\text { as Cryptoceroides cryptocerophagum) }\end{array}$ & $\mathrm{O}$ & $\begin{array}{l}\text { Also a myrmecomorph of Cephalotes pusillus (Klug) } \\
\text { (publ. as Zacryptocerus pusillus). Attacks from behind. } \\
\text { Holds dead ant as "protective shield." Females oviposit } \\
\text { near ant nest and defend egg sacs against worker ants. }\end{array}$ & {$[141-143]$} \\
\hline Aphantochilus spp. & Unk & Feed on cephalotine ants. & $\begin{array}{c}{[57,141-} \\
143]\end{array}$ \\
\hline Bucranium spp. & Unk & $\begin{array}{l}\text { Feed on cephalotine ants. Hold dead ants as protective } \\
\text { shield against attacks from other ants. }\end{array}$ & $\begin{array}{l}{[57,141-} \\
143]\end{array}$ \\
\hline $\begin{array}{l}\text { Mecaphesa californica (Banks) (publ. as } \\
\text { Misumenops californicus) }\end{array}$ & Unk & $\begin{array}{l}\text { Feeds on Pogonomyrmex rugosus in vegetation near ant } \\
\text { nests. }\end{array}$ & {$[93]$} \\
\hline $\begin{array}{l}\text { Mecaphesa coloradensis (Gertsch) (publ. as } \\
\text { Misumenops coloradensis) }\end{array}$ & Unk & $\begin{array}{l}\text { Feeds on alate females of Pogonomyrmex maricopa } \\
\text { Wheeler and } P \text {. desertorum Wheeler after they have } \\
\text { removed their wings and while resting on bushes } \\
\text { waiting for temperatures to drop in order to dig new } \\
\text { nest chambers. }\end{array}$ & {$[144]$} \\
\hline $\begin{array}{l}\text { Mecaphesa lepida (Thorell) (publ. as } \\
\text { Misumenops lepidus) }\end{array}$ & I & Occasionally feeds on ants. & [99] \\
\hline Misumenops argenteus (Rinaldi) & Probably I & $\begin{array}{l}17 \% \text { of prey are ants; mostly ants that get caught in } \\
\text { trichomes of plant Trichogoniopsis adenantha (OC), } \\
\text { where spider spends most of its time. }\end{array}$ & {$[145]$} \\
\hline $\begin{array}{l}\text { Runcinioides argenteus Mello-Leitão (publ. as } \\
\text { Misumenops argenteus) }\end{array}$ & Unk & Includes ants in diet. & {$[146]$} \\
\hline Saccodomus formivorus Rainbow & May be $\mathrm{F}$ or $\mathrm{O}$ & $\begin{array}{l}\text { Builds a basket-like web that appears to attract } \\
\text { wandering Iridomyrmex ants. Spider also uses } \\
\text { behavioral tactics-tapping ant with its own legs before } \\
\text { attacking. }\end{array}$ & {$[4,147]$} \\
\hline Thomisus onustus Walckenaer & I & $42.8 \%$ of diet consists of ants. & {$[147]$} \\
\hline Tmarus stoltzmanni Keyserling & $\mathrm{O}$ & $\begin{array}{l}\text { Feeds exclusively on ants; but only those without stings } \\
\text { such as dolichoderine and formicine ants. Uses frontal } \\
\text { attacks. May have sensory structures on 1st or } 2 \text { nd pair } \\
\text { of legs to detect chemical or tactile cues from ants. }\end{array}$ & {$[148]$} \\
\hline Other Tmarus sp. (from Australia) & Unk & Includes ants in diet. & {$[148,149]$} \\
\hline Xysticus californicus Keyserling & Unk & $\begin{array}{l}\text { Attacks harvester ants in California (cites unpubl. work } \\
\text { of Snelling). }\end{array}$ & {$[148,149]$} \\
\hline X. loeffleri Roewer & $\mathrm{R}$ & Ants comprise only a minor part of diet. & {$[150]$} \\
\hline Other Xysticus spp. & $\mathrm{I} / \mathrm{F}$ & $\begin{array}{l}\text { 30-35\% of diet of some spp. of Xysticus comprised of } \\
\text { ants. One spider seen preying on Pogonomyrmex salinus } \\
\text { Olsen. Spider seen on back of ant where it rode around, } \\
\text { biting ant until paralyzed. Spider bit at base of petiole. }\end{array}$ & {$[129,150]$} \\
\hline
\end{tabular}


Table 2: Continued.

\begin{tabular}{|c|c|c|c|}
\hline Spider myrmecophage & $\begin{array}{c}\text { Category of } \\
\text { myrmecophage* }^{*}\end{array}$ & Notes on biology & References \\
\hline \multicolumn{4}{|l|}{ Zodariidae } \\
\hline Diores spp. & Probably F or O & Feed on ants. & {$[151]$} \\
\hline Habronestes bradleyi (O. P.-Cambridge) & $\mathrm{O}$ & $\begin{array}{l}\text { Spider also myrmecomorph. Waves front legs around } \\
\text { when hunting ants. When legs are amputated, spider } \\
\text { has difficult time locating prey (Iridomyrmex purpureus } \\
\text { (Smith)). }\end{array}$ & {$[152-154]$} \\
\hline Lachesana insensibilis Jocqué & I & $\begin{array}{l}\text { Polyphagous but will eat ants smaller than themselves. } \\
\text { Uses different hunting behaviors for ants than for other } \\
\text { prey: bites, releases, re-approaches, bites again. }\end{array}$ & {$[155]$} \\
\hline Lachesana tarabaevi Zonstein and Ovtchinnikov & $\mathrm{F}$ & $\begin{array}{l}\text { Preys mostly on harvester ants in genus Messor and on } \\
\text { isopods. }\end{array}$ & {$[156]$} \\
\hline Pax islamita (Simon) & I & $\begin{array}{l}\text { Polyphagous but will eat ants smaller than themselves. } \\
\text { Uses different hunting behaviors for ants than for other } \\
\text { prey: bites, releases, re-approaches, bites again. }\end{array}$ & {$[155]$} \\
\hline Trygetus sexoculatus (O. P.-Cambridge) & $\mathrm{O}$ & $\begin{array}{l}\text { Paralysis latency longer for male and juvenile attacks } \\
\text { than for female attacks. }\end{array}$ & {$[157]$} \\
\hline Trygetus spp. & $\mathrm{O}$ & $\begin{array}{l}\text { Paralysis latency longer for male and juvenile attacks } \\
\text { than for female attacks. }\end{array}$ & {$[155,157]$} \\
\hline Zodariellum asiaticum (Tyschchenko) & $\mathrm{O}$ & $\begin{array}{l}\text { Specializes on formicine ants. Attacks other kinds of } \\
\text { ants readily but there is shorter paralysis latency for } \\
\text { formicine ants suggesting biochemical specificity of } \\
\text { venom for certain kinds of ants. }\end{array}$ & {$[155]$} \\
\hline Zodariellum spp. & Probably all $\mathrm{O}$ & Feed on ants. & {$[155]$} \\
\hline Zodarion cyrenaicum Denis & $\mathrm{O}$ & $\begin{array}{l}\text { Shows cooperative foraging behavior. But some } \\
\text { individuals steal prey from others (kleptoparasitism). } \\
\text { Paralysis latency longer for male and juvenile attacks } \\
\text { than for female attacks. }\end{array}$ & {$[157-159]$} \\
\hline Zodarion frenatum (Simon) & $\mathrm{O}$ & $\begin{array}{l}\text { Feeds on Cataglyphis bicolor (Fabricius). Locates nests } \\
\text { at night (maybe via odor cues?). Sometimes builds } \\
\text { retreats near nest. Digs open closed nest entrances, } \\
\text { which triggers ants to come out and repair. Spider } \\
\text { sometimes enters nest. Bites ant's legs and carries } \\
\text { paralyzed ant away from nest. Also kills ants in } \\
\text { morning when they emerge from nest. }\end{array}$ & $\begin{array}{l}{[158,160,} \\
161]\end{array}$ \\
\hline Zodarion germanicum (C. L. Koch) & $\mathrm{O}$ & $\begin{array}{l}\text { Myrmecomorph as well as myrmecophage. Waves 1st } \\
\text { legs as antennal illusion. Holds dead ant in chelicerae } \\
\text { and presents dead ant to approaching live ant while } \\
\text { "antennating" live ant with its own forelegs. } \\
\text { Presumably presenting both odor and tactile cues to } \\
\text { living ant to deceive it and avoid attack. Attacks } \\
\text { Cataglyphis bicolor (Fabricius). }\end{array}$ & {$[162,163]$} \\
\hline Zodarion jozefienae Bosmans & $\mathrm{O}$ & $\begin{array}{l}\text { Females and juveniles actively hunt ants. Mature males } \\
\text { are kleptoparasites on females' prey (spend energy on } \\
\text { mate searching, not prey capture). Sexual size } \\
\text { dimorphism (females larger). }\end{array}$ & $\begin{array}{c}{[161,164,} \\
165]\end{array}$ \\
\hline Zodarion lutipes (O. P.-Cambridge) & $\mathrm{O}$ & $\begin{array}{l}\text { Paralysis latency longer for male and juvenile attacks } \\
\text { than for female attacks. }\end{array}$ & {$[157]$} \\
\hline Zodarion nitidum (Audouin) & $\mathrm{O}$ & $\begin{array}{l}\text { Paralysis latency longer for male and juvenile attacks } \\
\text { than for female attacks. }\end{array}$ & {$[157]$} \\
\hline Zodarion rubidum Simon & $\mathrm{O}$ & $\begin{array}{l}\text { Myrmecomorph as well as myrmecophage. Waves 1st } \\
\text { legs as antennal illusion. Holds dead ant in chelicerae } \\
\text { and presents dead ant to approaching live ant while } \\
\text { "antennating" live ant with its own forelegs. } \\
\text { Presumably presenting both odor and tactile cues to } \\
\text { living ant to deceive it and avoid attack. }\end{array}$ & $\begin{array}{c}{[163,166-} \\
168]\end{array}$ \\
\hline
\end{tabular}


TABle 2: Continued.

\begin{tabular}{|c|c|c|c|}
\hline Spider myrmecophage & $\begin{array}{c}\text { Category of } \\
\text { myrmecophage* }\end{array}$ & Notes on biology & References \\
\hline Zodarion spp. & $\mathrm{O}$ & $\begin{array}{l}\text { All species obligate myrmecophages. Species also } \\
\text { imperfect myrmecomorphs. Documented hunting } \\
\text { various species. Do not survive well on non-ant diet. } \\
\text { Seem to be behaviorally adapted to hunt ants and seem } \\
\text { to have evolved nutritional limitations (non-ant prey } \\
\text { do not provide required nutrients). Attack from rear, } \\
\text { bite legs, retreat, may repeat, re-approach, pick up, and } \\
\text { carry away paralyzed ants. Move front legs while } \\
\text { hunting. Have femoral organ that may secrete chemical } \\
\text { involved in prey capture. }\end{array}$ & $\begin{array}{c}{[49,98,} \\
151,157, \\
158,160, \\
161,166, \\
168-174]\end{array}$ \\
\hline
\end{tabular}

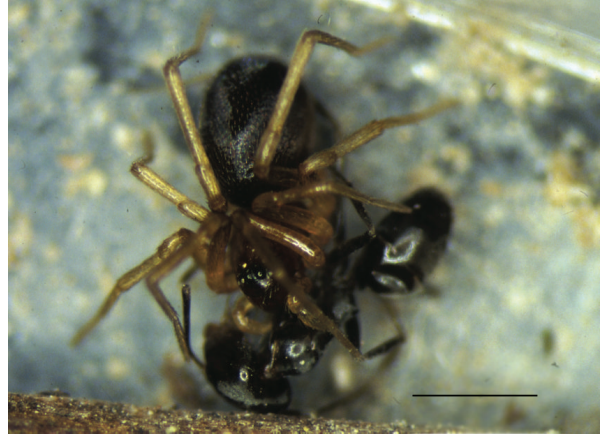

(a)

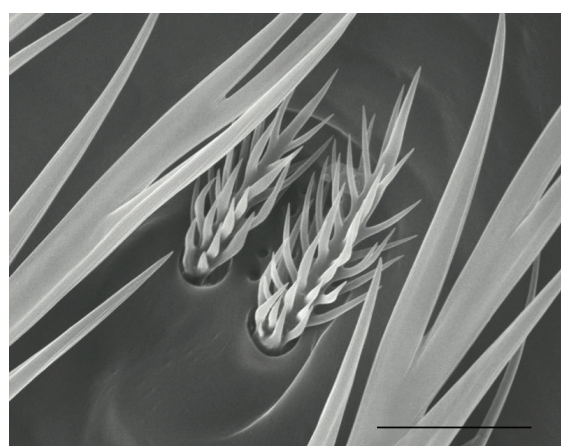

(b)

Figure 3: Myrmecophagy in spiders. (a) Zodarion rubidum Simon eating an ant. (b) Femoral organ on Z. rubidum. Note the pore openings in the chitin between the two specialized setae of the femoral organ. Scale bar in (a) $=1 \mathrm{~mm}$, scale bar in (b) $=10 \mu \mathrm{m}$. Photo of spider $(\mathrm{C}$ author, SEM of femoral organ (C) Catherine Tuell, used by permission.

suggesting that the spider may have organs on its front legs that pick up chemical cues from ants $[152,153]$. When these spiders detect chemical cues left by ants, they adopt prey capture posture and behavior [153]. Zodariid spiders in the genus Zodarion have a structure on the dorsolateral distal tip of the first femora called the femoral organ (Figure 3(b)). The organ consists of pores surrounded by specialized setae with secretory cells beneath the cuticle [171]. It is hypothesized that the femoral organ may release chemicals that somehow subdue the ants upon which the spiders prey (the setae may facilitate dispersion of the secretion) [171]. Zodarion rubidum Simon (and other species in the genus) move their front legs around while moving through the environment, similar to the antennal illusion of myrmecomorphs. The spiders seem to use the legs (perhaps via the femoral organs) to pick up cues about ants and conspecifics the spiders may encounter [166]. Recent work by Pekár and Jiroš [177] tested whether various species of myrmecomorphs including one myrmecophage, Zodarion alacre (Simon), were also chemical mimics of ants. They found little overlap in the chemical signature of the spiders and ants. Only a weak similarity in profiles was seen for the myrmecophage. The authors hypothesized that the femoral organ of Zodarion may be used to synthesize the compounds responsible for the similarity.

The family that includes the most specialized (stenophagous) myrmecophages is the Zodariidae (Table 2). Plesio- morphic representatives of this family, Lachesana insensibilis Jocqué and Pax islamita (Simon), are polyphagous but will eat ants and hunt ants differently from other prey [155]. Thus these plesiomorphic representatives of zodariids have behavioral preadaptations for hunting ants [155]. Pekár hypothesized that obligatory myrmecophagy may be a derived behavior because, within the Zodariidae, it is only seen in more recent taxa; primitive representatives of the family seem to be polyphagous [98].

4.3. Specialized Hunting Behaviors of Spider Myrmecophages. The majority of reluctant or indifferent myrmecophages will accept ants in the diet but typically show no specialized hunting behavior for these potentially dangerous predators, whereas the majority of facultative and obligatory myrmecophages have evolved specialized hunting strategies to subdue ants with minimum risk to themselves. It has been pointed out that "when predators evolve prey-specific capture behaviour for use against dangerous prey, they also tend to evolve distinct preferences for these dangerous prey" $[114,178]$. Hunting dangerous but abundant and/or high quality prey seems to select for behavioral plasticity in hunting behavior [105]. Such behavioral flexibility, or using different hunting strategies depending on the identity of the prey and on the circumstances, is common to both myrmecophagic and araneophagic spiders $[11,105,179]$. 
Many myrmecophagic spiders, particularly facultative or obligatory predators, live in close proximity to ant colonies, often building their webs directly over nest entrances or foraging trails or establishing retreats close to or adjacent to nest mounds $[44,93,122,124,126,127,130,131,134,136-$ $138,140,143,147,158,160,161,180]$. In addition to living in close proximity to their prey, these spiders also show specialized hunting behaviors as predicted for stenophagous predators hunting dangerous prey. Web-building myrmecophages (largely in the family Theridiidae, see Table 2) often build webs directly over ant foraging trails where they extend sticky silk strands down to the substrate. When an ant contacts the sticky strand, the ant is catapulted into the air and into the aboveground portion of the web where the spider waits $[4,93,124,127,136-138,140]$. The spider then typically bites the ant one or more times and, each time, the spider retreats until the ant is paralyzed or moribund [93, $130,131]$. The spider then typically carries the ant to a secluded retreat to feed or may even drop on a line to feed [93, $124,130,131,136-138$ ] (possibly to avoid detection from worker ants that may be attracted to alarm pheromones released by the captured ant). When catching non-ant prey, theridiids and other web building spiders do not typically retreat after biting the prey and may or may not carry the paralyzed prey to a different part of the web.

Non-web-building spiders, such as zodariids and salticids (the other families with large numbers of myrmecophagic species), show similar specialized hunting behaviors when attacking ants. For example, zodariids typically attack quickly from the rear of an ant, bite a leg, retreat, and may repeat this sequence several times until the ant is paralyzed. The spider then lifts the moribund ant and carries it to a secluded place to feed (Table 2 and $[98,158,162,167,168])$. It has been suggested that the paralyzed ant is used as a shield and a decoy to protect the zodariid from attacks by living ants; the paralyzed ant provides pheromone cues to a curious worker ant that passes by and may provide tactile cues as well $[163,166,167]$. Additional tactile cues are provided by the zodariid, which holds and waves its first pair of legs in front of its body like antennae [163]. The crab spider, Aphantochilus rogersi O. P.-Cambridge (Thomisidae), also uses the paralyzed ant as a shield, presumably protecting it from attacks by living ants $[142,143]$.

Many salticids lunge, rather than jump, at ant prey, then quickly bite, release, and bite again, each time retreating. Even nonmyrmecomorphic ant-eating salticids hunt ants by lunging. This is quite different from the usual stalk and pounce behavior shown to non-ant prey. Myrmecophagic salticids are much more cautious in their approach of ants and much more deliberate in where they bite the prey; some nearly always position themselves in front of the ant and bite the petiole or thorax $[92,105,106,108,109,114]$. Others nearly always attack ants from the rear, lunging at the gaster (not the appendages), but always retreating and waiting until the ant is quiescent before carrying it away $[99,106,109$, 110]. Many salticids keep their front legs extended off the ground when attacking an ant, away from the ant's mandibles $[108,113]$. The salticids do not show these behaviors when hunting non-ant prey. The salticids, Zenodorus durvillei
(Walckenaer), Z. metallescens (L. Koch), and Z. orbiculatus (Keyserling), are all facultative myrmecophages that feed on ants caught in other spiders' webs, but only if there is a safe way to capture these prey [106]. These species of Zenodorus will walk across a line of detritus to the captured ant or will even hang upside down above the ant and lunge at the prey caught in the web [106]. Some spider myrmecophages, particularly Callilepis nocturna (L) (Gnaphosidae), and species of Oecobius (Oecobiidae) aim for the ant's antenna when hunting then retreat and wait as is seen in nearly all other species of myrmecophages $[96,97,100]$.

4.4. Nutritional Costs of Myrmecophagy and a Stenophagous Diet. It has recently been demonstrated that at least some obligatory myrmecophages do not survive well on an antpoor diet; some even starve rather than hunt non-ant prey [173]. Thus obligatory myrmecophages show both behavioral limitations (i.e., spiders are reluctant to hunt non-ant prey) and nutritional limitations (i.e., non-ant prey do not provide required nutrients for survival) [173]. In fact, in order to obtain the necessary nutrients for survival, these spiders selectively consume particular parts of the bodies of their ant prey suggesting that "specialist predators can use a behavioral strategy to balance nutrient intake by selective exploitation of different prey body parts" [174]. These authors found, for example, that Zodarion rubidum preferentially fed on the foreparts of the ant body, which were richer in proteins, than on the gaster, which is higher in lipids but also contains possible toxins such as formic acid. These obligatory myrmecophages may take their specialization a step further by feeding primarily on one or two types of their preferred prey. For example, Zodarion species possess more effective venoms against particular groups of ants, such as formicine ants rather than myrmicine ants $[151,157,170]$. Zodarion germanicum (C. L. Koch) does better, in terms of growth and survival, on a diet that includes the preferred formicine ants than on a diet restricted to myrmicine ants [172].

\section{Discussion}

Research on spider myrmecomorphs has demonstrated, unequivocally, that these spiders are Batesian mimics and that the mimicry confers strong adaptive advantages to their survival. Some research has also tested how and why polymorphic and imperfect mimicry evolved. Future research on myrmecomorphic spiders should focus on the costs, trade-offs, and constraints inherent in the evolution of close morphological (and behavioral) resemblance to ants. These factors may have a significant impact on the accuracy of the resemblance. It is also important to identify the selective agents involved in this type of mimetic resemblance since the characteristics of the selective agents (e.g., the visual acuity of the selective agents and whether there is more than one actor in the drama) may explain the phenomena of polymorphic and imperfect mimicry.

Research on spider myrmecophiles has not been extensive in the years since the first review article. Nevertheless, the research that has been carried out, particularly on the species 
Gamasomorpha maschwitzi and Cosmophasis bitaeniata, is fascinating and demonstrates that the biology of these symbiotic spiders is closely linked to the lifestyle and biology of the host ants. From my earlier review article [5], and from Table 1, it is clear that many more species of myrmecophilic spiders can be studied and details of their biology explored. In the section on spider myrmecophiles, I suggest additional directions for future research such as: What adaptations are involved in colony integration? How do myrmecophiles disperse to neighboring colonies? Do all spider myrmecophiles mimic colony odors? To what extent can myrmecophiles interpret the chemical cues released by the hosts? What is the population structure of spider myrmecophiles (i.e., is the spider population within a single nest made up of close relatives)?

I also provide a summary of what is known about spider myrmecophages and present an extensive table listing all (I hope) records of spider myrmecophages from the literature. Recent research on these specialist predators has revealed the evolutionary costs and benefits of this stenophagous diet. It has also highlighted the extraordinary morphological and behavioral adaptations that have evolved enabling spiders to specialize on such dangerous prey.

Although spiders and ants seem unlikely co-evolutionary partners given ants' territorial aggressiveness and spiders' solitary lifestyles, it is clear that hundreds of species of spiders have evolved close relationships with ants. The information on spider myrmecomorphs, myrmecophiles, and myrmecophages included herein supplements information presented in the 1997 review [5]. The present paper includes the first comprehensive summary of the extensive research on myrmecophagic spiders. In addition, it presents an overview of the research carried out since 1997 that examines the evolutionary costs and benefits of the various spider-ant associations. One of my primary goals has been to provide ideas for new or expanded avenues of research on these fascinating arthropod relationships.

\section{Acknowledgments}

Sincere thanks to Kathy Honda for her extraordinary efforts and talent at tracking down citations for this paper. This paper would not have been possible without her assistance. Thanks are also due to Julie Whitman-Zai and two anonymous reviewers for helpful suggestions for improving the paper.

\section{References}

[1] R. F. Foelix, Biology of Spiders, Oxford University Press, 3rd edition, 2010.

[2] B. Hölldobler and E. O. Wilson, The Ants, Harvard University Press, Cambridge, Mass, USA, 1990.

[3] J. D. McIver and G. Stonedahl, "Myrmecomorphy: morphological and behavioral mimicry of ants," Annual Review of Entomology, vol. 38, pp. 351-379, 1993.

[4] M. A. Elgar, "Inter-specific associations involving spiders: kleptoparasitism, mimicry and mutualism," Memoirs. Queensland Museum, vol. 33, no. 2, pp. 411-430, 1993.
[5] P. E. Cushing, "Myrmecomorphy and myrmecophily in spiders: a review," Florida Entomologist, vol. 80, no. 2, pp. 165193, 1997.

[6] J. Reiskind, "Morphological adaptation for ant-mimicry in spiders," in Proceedings of the 5th International Congress of Arachnology, vol. 1971, pp. 221-226, Brno, Czech Republic, 1972.

[7] J. Reiskind, "Ant-mimicry in Panamanian clubionid and salticid spiders (Araneae: Clubionidae, Salticidae)," Biotropica, vol. 9, no. 1, pp. 1-8, 1977.

[8] S. P. Benjamin, "Taxonomic revision and phylogenetic hypothesis for the jumping spider subfamily Ballinae (Araneae, Salticidae)," Zoological Journal of the Linnean Society, vol. 142, no. 1, pp. 1-82, 2004.

[9] F. S. Ceccarelli, "New species of ant-mimicking jumping spiders of the genus Myrmarachne MacLeay, 1839 (Araneae: Salticidae) from north Queensland, Australia," Australian Journal of Entomology, vol. 49, pp. 245-255, 2010.

[10] R. R. Jackson and M. B. Willey, "The comparative study of the predatory behaviour of Myrmarachne, ant-like jumping spiders (Araneae: Salticidae)," Zoological Journal of the Linnean Society, vol. 110, no. 1, pp. 77-102, 1994.

[11] R. R. Jackson and S. D. Pollard, "Predatory behavior of jumping spiders," Annual Review of Entomology, vol. 41, pp. 287308, 1996.

[12] X. J. Nelson and R. R. Jackson, "Compound mimicry and trading predators by the males of sexually dimorphic Batesian mimics," Proceedings of the Royal Society B, vol. 273, no. 1584, pp. 367-372, 2006.

[13] C. L. Deeleman-Reinhold, "A new spider genus from Thailand with a unique ant mimicking device," The Natural History Bulletin of the Siam Society, vol. 40, no. 2, pp. 167-184, 1993.

[14] W. Dittrich, F. Gilbert, P. Green, P. Mcgregor, and D. Grewcock, "Imperfect mimicry: a pigeon's perspective," Proceedings of the Royal Society B, vol. 251, pp. 195-200, 1993.

[15] R. A. Johnstone, "The evolution of inaccurate mimics," Nature, vol. 418, pp. 524-526, 2002.

[16] A. Collart, "Quelques notes sur les Myrmarachne araignées oecophylliformes," Bulletin du Cercle Zoologique Congolais, vol. 5, pp. 117-118, 1929.

[17] A. Collart, "Quelques observations sur une araígnée mímetique," Revue de Zoologie et de Botanique Africaines, vol. 18, pp. 147-161, 1929.

[18] A. Collart, "Notes Complémentares sur Myrmarachne foenisex Simon araígnée myrmécomorphe du Congo Belge," Bulletin du Musée Royal d'Histoire Naturelle de Belgique, vol. 17, pp. 1-11, 1941.

[19] R. M. Borges, S. Ahmed, and C. V. Prabhu, "Male ant-mimicking salticid spiders discriminate between retreat silks of sympatric females: implications for pre-mating reproductive isolation," Journal of Insect Behavior, vol. 20, no. 4, pp. 389402, 2007.

[20] X. J. Nelson, "Visual cues used by ant-like jumping spiders to distinguish conspecifics from their models," Journal of Arachnology, vol. 38, no. 1, pp. 27-34, 2010.

[21] M. G. Rix, "A new genus and species of ant-mimicking jumping spider (Araneae: Salticidae) from Southeast Queensland, with notes on its biology," Memoirs of the Queensland Museum, vol. 43, no. 2, pp. 827-832, 1999.

[22] F. S. Ceccarelli, "Behavioral mimicry in Myrmarachne species (Araneae, Salticidae) from North Queensland, Australia," Journal of Arachnology, vol. 36, no. 2, pp. 344-351, 2008. 
[23] R. R. Jackson, "The biology of ant-like jumping spiders (Araneae, Salticidae): prey and predatory behaviour of Myrmarachne with particular attention to M. lupata from Queensland," Zoological Journal of the Linnean Society, vol. 88, no. 2, pp. 179-190, 1986.

[24] R. R. Jackson, X. J. Nelson, and K. Salm, “The natural history of Myrmarachne melanotarsa , a social ant-mimicking jumping spider," New Zealand Journal of Zoology, vol. 35, no. 3, pp. 225-235, 2008.

[25] W. Engelhardt, "Gestalt und Lebensweise der "Ameisenspinne" Synageles venator (Lucas) Zugleich ein Beitrag zur Ameisenmimikryforschung," Zoologischer Anzeiger, vol. 185, no. 5-6, pp. 317-334, 1970.

[26] B. Cutler, "Reduced predation on the antlike jumping spider Synageles occidentalis (Araneae: Salticidae)," Journal of Insect Behavior, vol. 4, no. 3, pp. 401-407, 1991.

[27] X. J. Nelson and R. R. Jackson, "Vision-based innate aversion to ants and ant mimics," Behavioral Ecology, vol. 17, no. 4, pp. 676-681, 2006.

[28] X. J. Nelson, R. R. Jackson, D. Li, A. T. Barrion, and G. B. Edwards, "Innate aversion to ants (Hymenoptera: Formicidae) and ant mimics: experimental findings from mantises (Mantodea)," Biological Journal of the Linnean Society, vol. 88, no. 1, pp. 23-32, 2006.

[29] X. J. Nelson and R. R. Jackson, "Collective Batesian mimicry of ant groups by aggregating spiders," Animal Behaviour, vol. 78, pp. 123-129, 2009.

[30] J.-N. Huang, R.-C. Cheng, D. Li, and I.-M. Tso, "Salticid predation as one potential driving force of ant mimicry in jumping spiders," Proceedings of the Royal Society B, vol. 278, pp. 1356-1364, 2011.

[31] C. A. Durkee, M. R. Weiss, and D. B. Uma, "Ant mimicry lessens predation on a North American jumping spider by larger salticid spiders," Environmental Entomology, vol. 40, no. 5, pp. 1223-1231, 2011.

[32] X. J. Nelson, "A predator's perspective of the accuracy of ant mimicry in spiders," Psyche, vol. 2012, Article ID 168549, 5 pages, 2012.

[33] M. Edmunds, "Do Malaysian Myrmarachne associate with particular species of ant?" Biological Journal of the Linnean Society, vol. 88, no. 4, pp. 645-653, 2006.

[34] O. H. Holen and R. A. Johnstone, "The evolution of mimicry under constraints," American Naturalist, vol. 164, no. 5, pp. 598-613, 2004.

[35] O. H. Holen and R. A. Johnstone, "Context-dependent discrimination and the evolution of mimicry," American Naturalist, vol. 167, no. 3, pp. 377-389, 2006.

[36] X. J. Nelson, R. R. Jackson, G. B. Edwards, and A. T. Barrion, "Living with the enemy: jumping spiders that mimic weaver ants," Journal of Arachnology, vol. 33, no. 3, pp. 813-819, 2005.

[37] F. Gilbert, "The evolution of imperfect mimicry," in Insect Evolutionary Ecology, M. D. E. Fellowes, G. J. Holloway, and J. Rolff, Eds., pp. 231-288, CABI, Wallingford, Wash, USA, 2005.

[38] G. B. Edwards and S. P. Benjamin, "A first look at the phylogeny of the Myrmarachninae, with rediscovery and redescription of the type species of Myrmarachne (Araneae: Salticidae)," Zootaxa, vol. 2309, pp. 1-29, 2009.

[39] D. W. Kikuchi and D. W. Pfennig, "High-model abundance may permit the gradual evolution of Batesian mimicry: an experimental test," Proceedings of the Royal Society B, vol. 277, pp. 1041-1048, 2010.
[40] S. Pekár and M. Jarab, "Assessment of color and behavioral resemblance to models by inaccurate myrmecomorphic spiders (Araneae)," Invertebrate Biology, vol. 130, no. 1, pp. 83-90, 2011.

[41] M. Edmunds, "Does mimicry of ants reduce predation by wasps on salticid spiders?" Memoirs - Queensland Museum, vol. 33, no. 2, pp. 507-512, 1993.

[42] R. Jocqué, "The prey of the mud-dauber wasp, Scelephron spirifex (Linneaeus), in Central Africa," Newsletter of the British Arachnological Society, vol. 51, p. 7, 1988.

[43] F. S. Ceccarelli and R. H. Crozier, "Dynamics of the evolution of Batesian mimicry: molecular phylogenetic analysis of antmimicking Myrmarachne (Araneae: Salticidae) species and their ant models," Journal of Evolutionary Biology, vol. 20, no. 1, pp. 286-295, 2007.

[44] X. J. Nelson, "Polymorphism in an ant mimicking jumping spider," Journal of Arachnology, vol. 38, no. 1, pp. 139-141, 2010.

[45] W. Fannes and R. Jocqué, "Ultrastructure of Antoonops, a new ant-mimicking genus of afrotropical Oonopidae (Araneae) with complex internal genitalia," American Museum Novitates, vol. 3614, pp. 1-30, 2008.

[46] M. Joron, "Polymorphic mimicry, microhabitat use, and sexspecific behaviour," Journal of Evolutionary Biology, vol. 18, pp. 547-556, 2005.

[47] M. P. Speed and G. D. Ruxton, "Imperfect Batesian mimicry and the conspicuousness costs of mimetic resemblance," American Naturalist, vol. 176, no. 1, pp. E1-E14, 2010.

[48] T. N. Sherratt, "The evolution of imperfect mimicry," Behavioral Ecology, vol. 13, no. 6, pp. 821-826, 2002.

[49] M. Edmunds, "Why are there good and poor mimics?" Biological Journal of the Linnean Society, vol. 70, no. 3, pp. 459466, 2000.

[50] C. J. Duncan and P. M. Sheppard, "Sensory discrimination and its role in the evolution of Batesian mimicry," Behaviour, vol. 24, no. 3, pp. 269-282, 1965.

[51] J. Mappes and R. V. Alatalo, "Batesian mimicry and signal accuracy," Evolution, vol. 51, no. 6, pp. 2050-2053, 1997.

[52] S. Pekár, M. Jarab, L. Fromhage, and M. E. Herberstein, "Is the evolution of inaccurate mimicry a result of selection by a suite of predators? A case study using myrmecomorphic spiders," American Naturalist, vol. 178, no. 1, pp. 124-134, 2011.

[53] X. J. Nelson, D. Li, and R. R. Jackson, "Out of the frying pan and into the fire: a novel trade-off for Batesian mimics," Etho$\log y$, vol. 112, no. 3, pp. 270-277, 2006.

[54] X. J. Nelson, R. R. Jackson, and D. Li, "Conditional use of honest signaling by a Batesian mimic," Behavioral Ecology, vol. 17, no. 4, pp. 575-580, 2006.

[55] S. Pekár and M. Jarab, "Life-history constraints in inaccurate Batesian myrmecomorphic spiders (Araneae: Corinnidae, Gnaphosidae)," European Journal of Entomology, vol. 108, no. 2, pp. 255-260, 2011.

[56] W. S. Bristowe, The Comity of Spiders I, Ray Society, London, UK, 1939.

[57] W. S. Bristowe, The Comity of Spiders II, Ray Society, London, UK, 1941.

[58] M. Edmunds, "On the association between Myrmarachne spp. (Salticidae) and ants," Bulletin of the British Arachnological Society, vol. 4, pp. 149-160, 1978.

[59] F. R. Wanless, "A revision of the spider genera Belippo and Myrmarachne (Araneae: Salticidae) in the Ethiopian region," Bulletin of the British Museum (Natural History), Zoological Series, vol. 33, pp. 1-139, 1978. 
[60] B. L. Bradoo, "A new ant-like spider of the genus Myrmarachne (Salticidae) from India," Current Science, vol. 49, no. 10, pp. 387-388, 1980.

[61] J.-L. Boevé, “Association of some spiders with ants," Revue Suisse de Zoologie, vol. 99, pp. 81-85, 1992.

[62] H. Donisthorpe, The Guests of British Ants, Their Habits and Life Histories, Routledge and Sons, London, UK, 1927.

[63] N. Platnick, "The world spider catalog, version 12.0," American Museum of Natural History, http://research.amnh.org/ iz/spiders/catalog.

[64] K. Thaler, A. Kofler, and E. Meyer, "Fragmenta faunistica Tirolensia-IX," Berichte des Naturwissenschaftlich-Medizinischen Vereins in Innsbruck, vol. 77, pp. 225-243, 1990.

[65] J. Wunderlich, "Beschreibung bisher unbekannter Spinnenarten und Gattungen aus Malaysia und Indonesien (Arachnida: Araneae: Oonopidae, Tetrablemidae, Telemidae und Dictynidae)," Beitraege zur Araneologie, vol. 4, pp. 559-580, 1994.

[66] L. Fage, "Quelques Arachnides provenant de fourmilières ou de termitières du Costa Rica," Bulletin Museum National d'Histoire Naturelle, vol. 4, pp. 369-376, 1938.

[67] V. Witte, H. Hänel, A. Weissflog, H. Rosli, and U. Maschwitz, "Social integration of the myrmecophilic spider Gamasomorpha maschwitzi (Araneae: Oonopidae) in colonies of the South East Asian army ant, Leptogenys distinguenda (Formicidae: Ponerinae)," Sociobiology, vol. 34, pp. 145-159, 1999.

[68] V. Witte, A. Leingärtner, L. Sabab, R. Hashim, and S. Foitzik, "Symbiont microcosm in an ant society and the diversity of interspecific interactions," Animal Behaviour, vol. 76, pp. 1477-1486, 2008.

[69] V. Witte, S. Foitzik, R. Hashim, U. Maschwitz, and S. Schulz, "Fine tuning of social integration by two myrmecophiles of the ponerine army ant, Leptogenys distinguenda," Journal of Chemical Ecology, vol. 35, no. 3, pp. 355-367, 2009.

[70] M. Birabén, "Nuevas "Gamasomorphinae" de la Argentina," Notas del Museo, Universidad Nacional de Eva Perón, vol. 17, no. 152, pp. 181-212, 1954.

[71] B. Gray, "Notes on the biology of the ant species Myrmecia dispar (Clark) (Hymenoptera: Formicidæ)," Insectes Sociaux, vol. 18, no. 2, pp. 71-109, 1971.

[72] R. A. Allan and M. A. Elgar, "Exploitation of the green tree ant, Oecophylla smaragdina, by the salticid spider Cosmophasis bitaeniata," Australian Journal of Zoology, vol. 49, no. 2, pp. 129-137, 2001.

[73] R. A. Allan, R. J. Capon, W. V. Brown, and M. A. Elgar, "Mimicry of host cuticular hydrocarbons by salticid spider Cosmophasis bitaeniata that preys on larvae of tree ants Oecophylla smaragdina," Journal of Chemical Ecology, vol. 28, no. 4, pp. 835-848, 2002.

[74] M. A. Elgar and R. A. Allan, "Predatory spider mimics acquire colony-specific cuticular hydrocarbons from their ant model prey," Naturwissenschaften, vol. 91, no. 3, pp. 143-147, 2004.

[75] M. A. Elgar and R. A. Allan, "Chemical mimicry of the ant Oecophylla smaragdina by the myrmecophilous spider Cosmophasis bitaeniata is it colony-specific?" Journal of Ethology, vol. 24, no. 3, pp. 239-246, 2006.

[76] R. H. Crozier, P. S. Newey, E. A. Schlüns, and S. K. A. Robson, "A masterpiece of evolution-Oecophylla weaver ants (Hymenoptera: Formicidae)," Myrmecological News, vol. 13, pp. $57-71,2010$.
[77] X. J. Nelson and R. R. Jackson, "The influence of ants on the mating strategy of a myrmecophilic jumping spider (Araneae, Salticidae)," Journal of Natural History, vol. 43, no. 1112, pp. 713-735, 2009.

[78] C. F. Roewer, "Zwei myrmecophile Spinnen-Arten Brasiliens," Veröffentlichungen Deutschen Kolon, Uebersee Museum, Bremen, vol. 1, pp. 193-197, 1935.

[79] P. E. Cushing, "Population structure of the ant nest symbiont Masoncus pogonophilus (Araneae: Linyphiidae)," Annals of the Entomological Society of America, vol. 91, no. 5, pp. 626631, 1998.

[80] P. E. Cushing, "Description of the spider Masoncus pogonophilus (Araneae, Linyphiidae), a harvester ant myrmecophile," Journal of Arachnology, vol. 23, pp. 55-59, 1995.

[81] S. D. Porter, "Masoncus spider: a miniature predator of Collembola in harvester ant colonies," Psyche, vol. 92, no. 1, pp. 145-150, 1985.

[82] M. Erthal Jr. and A. Tonhasca Jr., "Attacobius attarum spiders (Corinnidae): myrmecophilous predators of immature forms of the leaf-cutting ant Atta sexdens (Formicidae)," Biotropica, vol. 33, no. 2, pp. 374-376, 2001.

[83] J. A. Thomas, K. Schönrogge, and G. W. Elmes, "17. Specializations and host associations of social parasites of ants," in Insect Evolutionary Ecology, M. D. E. Fellowes, G. J. Holloway, and J. Rolff, Eds., pp. 479-518, Royal Entomological Society, CABI Publishing, UK, 2005.

[84] A. Lenoir, P. D’Ettorre, C. Errard, and A. Hefetz, "Chemical ecology and social parasitism in ants," Annual Review of Entomology, vol. 46, pp. 573-599, 2001.

[85] R. W. Howard, R. D. Akre, and W. B. Garnett, "Chemical mimicry of an obligate predator of carpenter ants (Hymenoptera: Formicidae)," Annals of the Entomological Society of America, vol. 83, pp. 607-616, 1990.

[86] K. Dettner and C. Liepert, "Chemical mimicry and camouflage," Annual Review of Entomology, vol. 39, pp. 129-154, 1994.

[87] N. I. Platnick and R. L. C. Baptista, "On the spider genus Attacobius (Araneae, Dionycha)," American Museum Novitates, vol. 3120, pp. 1-9, 1995.

[88] A. C. Cole Jr., Pogonomyrmex harvester ants: a study of the Genus in North America, The University of Tennessee Press, Knoxville, Tenn, USA, 1968.

[89] J. B. Gentry, "Response to predation by colonies of the Florida harvester ant, Pogonomyrmex badius," Ecology, vol. 55, pp. 1328-1338, 1974.

[90] J. Antonovics, "Ecological genetics of metapopulations: the Silene-Ustilago plant-pathogen system," in Ecological Genet$i c s$, L. A. Real, Ed., pp. 3-17, Princeton University Press, Princeton, NJ, USA, 1994.

[91] J. Wunderlich, "Ober "Ameisenspinnen" in Mitteleuropa (Arachnida: Araneae)," Beitrage Araneologie, vol. 4, pp. 447470, 1994.

[92] E. F. Huseynov, R. R. Jackson, and F. R. Cross, “The meaning of predatory specialization as illustrated by Aelurillus m-nigrum, an ant-eating jumping spider (Araneae: Salticidae) from Azerbaijan,” Behavioural Processes, vol. 77, no. 3, pp. 389399, 2008.

[93] W. P. MacKay, "The effect of predation of western widow spiders (Araneae: Theridiidae) on harvester ants (Hymenoptera: Formicidae)," Oecologia, vol. 53, pp. 406-411, 1982.

[94] A. D. Austin and A. D. Blest, "The biology of two Australian species of dinopid spider," Journal of Zoology, vol. 189, pp. 145-156, 1979. 
[95] A. S. Dippenaar-Schoeman, "A revision of the African genus Seothyra Purcell (Araneae: Eresidae)," Cymbebasia, vol. 12, pp. 35-160, 1991.

[96] G. Heller, Zur Biologie der ameisenfressenden Spinne Callilepis nocturna Linnaeus 1758 (Araneae, Drassodidae), Dissertation, Johannes Gutenberg-Universität, Mainz, Germany, 1974.

[97] G. Heller, "Zum Beutefangverhalten der ameisenfressenden Spinne Callilepis nocturna (Arachnida: Araneae: Drassodidae)," Entomolgische Germanica, vol. 3, pp. 100-103, 1976.

[98] S. Pekár, "Predatory behavior of two European ant-eating spiders (Araneae, Zodariidae)," Journal of Arachnology, vol. 32, no. 1, pp. 31-41, 2004.

[99] K. Wing, "Tutelina similis (Araneae: Salticidae): an ant mimic that feeds on ants," Journal of the Kansas Entomological Society, vol. 56, no. 1, pp. 55-58, 1983.

[100] L. Glatz, "Zur Biologie und Morphologie von Oecobius annulipes Lucas (Araneae, Oecobiidae)," Zoomorphology, vol. 61, no. 2, pp. 185-214, 1967.

[101] N. A. Weber, "Fungus-growing ants and their fungi: Cyphomyrmex costatus," Ecology, vol. 38, pp. 480-494, 1957.

[102] E. F. O. Huseynov, "The prey of the lynx spider Oxyopes globifer (Araneae, Oxyopidae) associated with a semidesert dwarf shrub in Azerbaijan," Journal of Arachnology, vol. 34, no. 2, pp. 422-426, 2006.

[103] M. Nyffeler, D. A. Dean, and W. L. Sterling, "Diets, feeding specialization, and predatory role of two lynx spiders, Oxyopes salticus and Peucetia viridans (Araneae: Oxyopidae), in a Texas cotton agroecosystem," Environmental Entomology, vol. 21, pp. 1457-1465, 1992.

[104] W. P. MacKay and S. B. Vinson, "Evaluation of the spider Steatoda triangulosa (Araneae: Theridiidae) as a predator of the red imported fire ant (Hymenoptera: Formicidae)," Journal of the New York Entomological Society, vol. 97, no. 2, pp. 232-233, 1989.

[105] D. Li, R. R. Jackson, and D. P. Harland, "Prey-capture techniques and prey preferences of Aelurillus aeruginosus, $A$. cognatus, and $A$. kochi, ant-eating jumping spiders (Araneae: Salticidae) from Israel," Israel Journal of Zoology, vol. 45, pp. 341-359, 1999.

[106] R. R. Jackson and D. Li, "Prey-capture techniques and prey preferences of Zenodorus durvillei, $Z$. metallescens and $Z$. orbiculatus, tropical ant-eating jumping spiders (Araneae: Salticidae) from Australia," New Zealand Journal of Zoology, vol. 28, pp. 299-341, 2001.

[107] G. B. Edwards, J. F. Carroll, and W. H. Whitcomb, "Stoidis aurata (Araneae: Salticidae), a spider predator of ants," The Florida Entomologist, vol. 57, no. 4, pp. 337-346, 1975.

[108] R. R. Jackson and A. van Olphen, "Prey-capture techniques and prey preferences of Corythalia canosa and Pystira orbiculata, ant-eating jumping spiders (Araneae, Salticidae)," Journal of Zoology, London, vol. 223, pp. 577-591, 1991.

[109] R. R. Jackson, D. Li, A. T. Barron, and G. B. Edwards, "Preycapture techniques and prey preferences of nine species of ant-eating jumping spiders (Araneae: Salticidae) from the Philippines," New Zealand Journal of Zoology, vol. 25, pp. 249-272, 1998.

[110] R. R. Jackson and A. van Olphen, "Prey-capture techniques and prey preferences of Chrysilla, Natta and Siler, ant-eating jumping spiders (Araneae, Salticidae) from Kenya and Sri Lanka," Journal of Zoology, London, vol. 227, pp. 163-170, 1992.

[111] N. Ii, "Observations on a strange plundering behaviour in salticid spiders," Acta Arachnologica, vol. 27, pp. 209-212, 1977 (Japanese).
[112] H. S. Fitch, "Spiders of the University of Kansas Natural History Reservation and Rockefeller Experimental Tract," Miscellaneous Publications of the University of Kansas Museum of Natural History, vol. 33, pp. 1-202, 1963.

[113] B. Cutler, "Ant predation by Habrocestum pulex (Hentz) (Araneae: Salticidae)," Zoologischer Anzeiger, vol. 204, no. 12, pp. 97-101, 1980.

[114] D. Li, R. R. Jackson, and B. Cutler, "Prey-capture techniques and prey preferences of Habrocestum pulex, an ant-eating jumping spider (Araneae, Salticidae) from North America," Journal of Zoology, London, vol. 240, pp. 551-562, 1996.

[115] J. L. Cloudsley-Thompson, "Notes on Arachnida 12. Mating habits of Hasarius adansoni Say," Entomologist's Monthly Magazine, vol. 85, pp. 211-212, 1949.

[116] R. R. Jackson, "Prey of the jumping spider, Phidippus johnsoni (Araneae: Salticidae)," Journal of Arachnology, vol. 5, no. 2, pp. 145-149, 1977.

[117] K. Nakahira, "Observations on a jumping spider Silerella vittata that attacks ants (2)," Atypus, vol. 9, p. 1, 1955 (Japanese).

[118] S. Jo, "Observations on jumping spider that carries off ant larva," Atypus, vol. 32, p. 11, 1964 (Japanese).

[119] K. Nakahira, "Ants on which jumping spider Silerella vittata preys," Atypus, vol. 61, p. 15, 1973 (Japanese).

[120] Y. Touyama, Y. Ihara, and F. Ito, "Argentine ant infestation affects the abundance of the native myrmecophagic jumping spider Siler cupreus Simon in Japan," Insectes Sociaux, vol. 55, no. 2, pp. 144-146, 2008.

[121] B. J. Kaston, "Spiders of Connecticut," State of Connecticut Geological and Natural History Survey Bulletin, vol. 70, pp. 1-374, 1981.

[122] B. Hölldobler, "Steatoda fulva (Theridiidae), a spider that feeds on harvester ants," Psyche, vol. 77, no. 2, pp. 202-208, 1970.

[123] J. T. Moggridge, Harvesting ants and trapdoor spiders with notes and observations on their habits and dwellings, London, UK, 1873.

[124] E. Nørgaard, "Environment and behavior of Theridion saxatile," Oikos, vol. 7, pp. 159-192, 1956.

[125] Y. Umeda, A. Shinkai, and T. Miyashita, "Prey composition of three Dipoena spp. (Araneae: Theridiidae) specializing on ants," Acta Arachnologica, vol. 45, no. 1, pp. 95-99, 1996.

[126] H. C. McCook, The Natural History of the Agricultural Ant of Texas. A Monograph of the Habits, Architecture and Structure of Pogonomyrmex barbatus, Lippincott and Co., Philadelphia, PA, USA, 1880.

[127] S. D. Porter and D. A. Eastmond, "Euryopis coki (Theridiidae), a spider that preys on Pogonomyrmex ants," Journal of Arachnology, vol. 10, no. 3, pp. 275-277, 1982.

[128] L. Berland, "Contribution a l'étude de la biologie des arachnides," Archives de Zoologie Expérimentale et Générale, vol. 76, no. 1, pp. 1-23, 1933.

[129] W. H. Clark and P.E. Blom, "Notes on spider (Theridiidae, Salticidae) predation of the harvester ant, Pogonomyrmex salinus Olsen (Hymenoptera: Formicidae: Myrmicinae), and a possible parasitoid fly (Chloropidae)," Great Basin Naturalist, vol. 52, pp. 385-386, 1992.

[130] A. F. Archer, "The Theridiidae or comb-footed spiders of Alabama," Museum Papers of the Alabama Museum of Natural History, vol. 22, pp. 5-67, 1946.

[131] J. E. Carico, "Predatory behavior of Euryopis funeris (Hentz) (Araneae: Theridiidae) and the evolutionary significance of web reduction," Symposium of the Zoological Society of London, vol. 42, pp. 51-58, 1978. 
[132] H. W. Levi, "Spiders of the genus Euryopis from North and Central America," American Museum Novitates, vol. 1666, pp. $1-48,1954$.

[133] W. J. Gertsch, American Spiders, Van Nostrand Reinhold, New York, NY, USA, 2nd edition, 1979.

[134] J. W. Abalos, "Las arañas del género Latrodectus en la Argentina," Obra del Centenario del Museo de La Plata, vol. 6, pp. 29-51, 1980.

[135] M. Nyffeler, D. A. Dean, and W. L. Sterling, "The southern black widow spider Latrodectus mactans (Araneae, Theridiidae), as a predator of the red imported fire ant, Solenopsis invicta (Hymenoptera, Formicidae), in Texas cotton fields," Journal of Applied Entomology, vol. 106, pp. 52-57, 1988.

[136] A. Shulov and A. Weissman, "Notes on the life habitats and potency of the venom of the three Latrodectus spider species in Israel," Ecology, vol. 40, pp. 515-518, 1939.

[137] A. Shulov, "On the biology of two Latrodectus spiders in Palestine," in Proceedings of the Linnean Society, London, vol. 152, pp. 309-328, 1940.

[138] A. Shulov, "Biology and ecology of venomous animals in Israel," Memórias do Instituto Butantan, vol. 33, pp. 93-99, 1966.

[139] H. W. Levi, "The spider genera Crustulina and Steatoda in North America, Central America, and the West Indies (Araneae, Theridiidae)," Bulletin of the Museum of Comparative Zoology, vol. 117, no. 3, pp. 367-424, 1957.

[140] D. Cooper, A. Williamson, and C. Williamson, "Deadly deception," Geo: Australia's Geographical Magazine, vol. 12, no. 1, pp. 86-95, 1990.

[141] S. de T. Piza, "Novas espécies de aranhas myrmecomorphas do Brazil e considerações sobre o seu mimetismo," Revista do Museu Paulista, vol. 23, pp. 307-319, 1937.

[142] P. S. Oliveira and I. Sazima, "The adaptive bases of ant-mimicry in a neotropical aphantochilid spider (Araneae: Aphantochilidae)," Biological Journal of the Linnean Society, vol. 22, pp. 145-155, 1984.

[143] L. M. Castanho and P. S. Oliveira, "Biology and behavior of the neotropical ant-mimicking spider Aphantochilus rogersi (Araneae: Aphantochilidae): nesting, maternal care and ontogeny of ant-hunting techniques," Journal of Zoology, London, vol. 242, pp. 643-650, 1997.

[144] B. Hölldobler, "The behavioral ecology of mating in harvester ants (Hymenoptera: Formicidae: Pogonomyrmex)," Behavioral Ecology and Sociobiology, vol. 1, pp. 405-423, 1976.

[145] Q. R. Romero and J. Vasconcellos-Neto, "Natural history of Misumenops argenteus (Thomisidae): seasonality and diet on Trichogoniopsis adenantha (Asteraceae)," Journal of Arachnology, vol. 31, no. 2, pp. 297-304, 2003.

[146] E. F. Huseynov, "Natural prey of the crab spider Thomisus onustus (Araneae: Thomisidae), an extremely powerful predator of insects," Journal of Natural History, vol. 41, no. 3740, pp. 2341-2349, 2007.

[147] K. C. McKeown, Australian Spiders: Their Lives and Habits, Angus \& Robertson, Sydney, Australia, 1952.

[148] Y. D. Lubin, "An ant eating crab spider from the Galapagos," Noticias de Galapagos, vol. 37, pp. 18-19, 1983.

[149] R. Mascord, Spiders of Australia, A. H. and A. W. Reed Pty. Ltd., Sydney, Australia, 1980.

[150] E. F.O. Guseinov, "The prey of a lithophilous crab spider Xysticus loeffleri (Araneae, Thomisidae)," Journal of Arachnology, vol. 34, no. 1, pp. 37-45, 2006.
[151] S. Pekár, "Capture efficiency of an ant-eating spider, Zodariellum asiaticum (Araneae: Zodariidae), from Kazakhstan," Journal of Arachnology, vol. 37, no. 3, pp. 388-391, 2009.

[152] R. A. Allan, M. A. Elgar, and R. J. Capon, "Exploitation of an ant chemical alarm signal by the zodariid spider Habronestes bradleyi Walckenaer," Proceedings of the Royal Society B, vol. 263, no. 1366, pp. 69-73, 1996.

[153] R. J. Clark, R. R. Jackson, and B. Cutler, "Chemical cues from ants influence predatory behavior in Habrocestum pulex, an ant-eating jumping spider (Araneae, Salticidae)," Journal of Arachnology, vol. 28, no. 3, pp. 309-318, 2000.

[154] H. Gibb, "Dominant meat ants affect only their specialist predator in an epigaeic arthropod community," Oecologia, vol. 136, no. 4, pp. 609-615, 2003.

[155] S. Pekár and Y. Lubin, "Prey and predatory behavior of two zodariid species (Araneae, Zodariidae)," Journal of Arachnology, vol. 37, no. 1, pp. 118-121, 2009.

[156] S. L. Zonstein and S. V. Ovtschinnikov, "A new Central Asian species of the spider genus Lachesana Strand, 1932 (Araneae, Zodariidae: Lachesaninae)," TETHYS Entomological Research, vol. 1, pp. 59-62, 1999.

[157] S. Pekár, J. Král, and Y. Lubin, "Natural history and karyotype of some ant-eating zodariid spiders (Araneae, Zodariidae) from Israel," Journal of Arachnology, vol. 33, no. 1, pp. 50-62, 2005.

[158] R. D. Harkness, "Further observations on the relation between an ant, Cataglyphis bicolor (F.) (Hymenoptera, Formicidae) and a spider, Zodarium frenatum (Simon) (Araneae, Zodariidae)," Entomologist's Monthly Magazine, vol. 112, pp. 111-121, 1977.

[159] S. Pekár, M. Hrušková, and Y. Lubin, "Can solitary spiders (Araneae) cooperate in prey capture?” Journal of Animal Ecology, vol. 74, no. 1, pp. 63-70, 2005.

[160] R. D. Harkness, "The relation between an ant, Cataglyphis bicolor (F.) (Hymenoptera, Formicidae) and a spider, Zodarium frenatum (Simon) (Araneae, Zodariidae)," Entomologist's Monthly Magazine, vol. 111, pp. 141-146, 1976.

[161] M. L. R. Harkness and R. D. Harkness, "Predation of an ant (Cataglyphis bicolor (F.) Hymenoptera, Formicidae) by a spider (Zodarion frenatum (Simon) Araneae, Zodariidae) in Greece," Entomologist's Monthly Magazine, vol. 128, pp. 147156, 1992.

[162] P. Schneider, "Ameisenjagende Spinnen (Zodariidae) an Cataglyphis-Nestern in Afghanistan," Zoologischer Anzeiger, Leipzig, vol. 187, no. 3-4, pp. 199-201, 1971.

[163] S. Pekár and J. Král, "Mimicry complex in two central European zodariid spiders (Araneae: Zodariidae): how Zodarion deceives ants," Biological Journal of the Linnean Society, vol. 75, no. 4, pp. 517-532, 2002.

[164] M. Martišová, T. Bilde, and S. Pekár, "Sex-specific kleptoparasitic foraging in ant-eating spiders," Animal Behaviour, vol. 78, no. 5, pp. 1115-1118, 2009.

[165] S. Pekár, M. Martišová, and T. Bilde, "Intersexual trophic niche partitioning in an ant-eating spider (Araneae: Zodariidae)," PLoS ONE, vol. 6, no. 1, pp. 1-7, 2011.

[166] J. M. Couvreur, "Le comportement d'presentation d'un leurre' chez Zodarion rubidium (Araneae, Zodariidae)," in Proceedings of the 12th European Colloquium of Arachnology, Paris, M. L. Célérier, J. Heurtault, and C. Rollard, Eds., vol. 1, pp. 75-79, Bulletin de la Sociéte Europíene Arachnologique, Paris, France, 1990.

[167] J. M. Couvreur, "Quelques aspects de la biologie de Zodarion rubidium, Simon, 1914,", Nieuwsbrief van de Belgische Arachnologische Vereniging, vol. 7, pp. 7-15, 1990. 
[168] P. E. Cushing and R. G. Santangelo, "Notes on the natural history and hunting behavior of an ant eating zodariid spider (Arachnida, Araneae) in Colorado," Journal of Arachnology, vol. 30, no. 3, pp. 618-621, 2002.

[169] R. Jocqué and J. Billen, "The femoral organ of the Zodariinae (Araneae, Zodariidae)," Revue de Zoologie Africaine, vol. 101, pp. 165-170, 1987.

[170] S. Pekár, J. Král, A. Malten, and C. Komposch, “Comparison of natural histories and karyotypes of two closely related anteating spiders, Zodarion hamatum and Z. italicum (Araneae, Zodariidae)," Journal of Natural History, vol. 39, no. 19, pp. 1583-1596, 2005.

[171] S. Pekár and J. Šobotník, "Comparative study of the femoral organ in Zodarion spiders (Araneae: Zodariidae)," Arthropod Structure and Development, vol. 36, pp. 105-112, 2007.

[172] S. Pekár, S. Toft, M. Hrušková, and D. Mayntz, "Dietary and prey-capture adaptations by which Zodarion germanicum, an ant-eating spider (Araneae: Zodariidae), specializes on the Formicinae," Naturwissenschaften, vol. 95, no. 3, pp. 233239, 2008.

[173] S. Pekár and S. Toft, "Can ant-eating Zodarion spiders (Araneae: Zodariidae) develop on a diet optimal for euryphagous arthropod predators?" Physiological Entomology, vol. 34, pp. 195-201, 2009.

[174] S. Pekár, D. Mayntz, T. Ribeiro, and M. E. Herberstein, "Specialist ant-eating spiders selectively feed on different body parts to balance nutrient intake," Animal Behaviour, vol. 79, no. 6, pp. 1301-1306, 2010.

[175] A. P. Mathew, "Observations on the habits of the two spider mimics of the red ant Oecophylla smaragdina (Fabr.)," Journal of the Bombay Natural History Society,, vol. 52, pp. 249-263, 1954.

[176] X. J. Nelson, R. R. Jackson, S. D. Pollard, G. B. Edwards, and A. T. Barrion, "Predation by ants on jumping spiders (Araneae: Salticidae) in the Philippines," New Zealand Journal of Zoology, vol. 31, no. 1, pp. 45-56, 2004.

[177] S. Pekár and P. Jiroš, "Do ant mimics imitate cuticular hydrocarbons of their models?" Animal Behaviour, vol. 82, no. 5, pp. 1193-1199, 2011.

[178] D. Li and R. R. Jackson, "Prey-specific capture behaviour and prey preferences of myrmecophagic and araneophagic jumping spiders," Revue Suisse de Zoologie Hors Serie, pp. 423-436, 1996.

[179] D. B. Richman and R. R. Jackson, "A review of the ethology of jumping spiders (Araneae: Salticidae)," Bulletin of the British Arachnological Society, vol. 9, pp. 33-37, 1992.

[180] W. H. Clark, "Predation on the harvester ant, Pogonomyrmex tenuispina Forel (Hymenoptera: Formicidae), by the spider, Steatoda fulva (Keyserling) (Araneae: Theridiidae) in Baja California Sur, México," Southwestern Entomologist, Scientific Note, vol. 21, no. 2, pp. 213-217, 1996. 

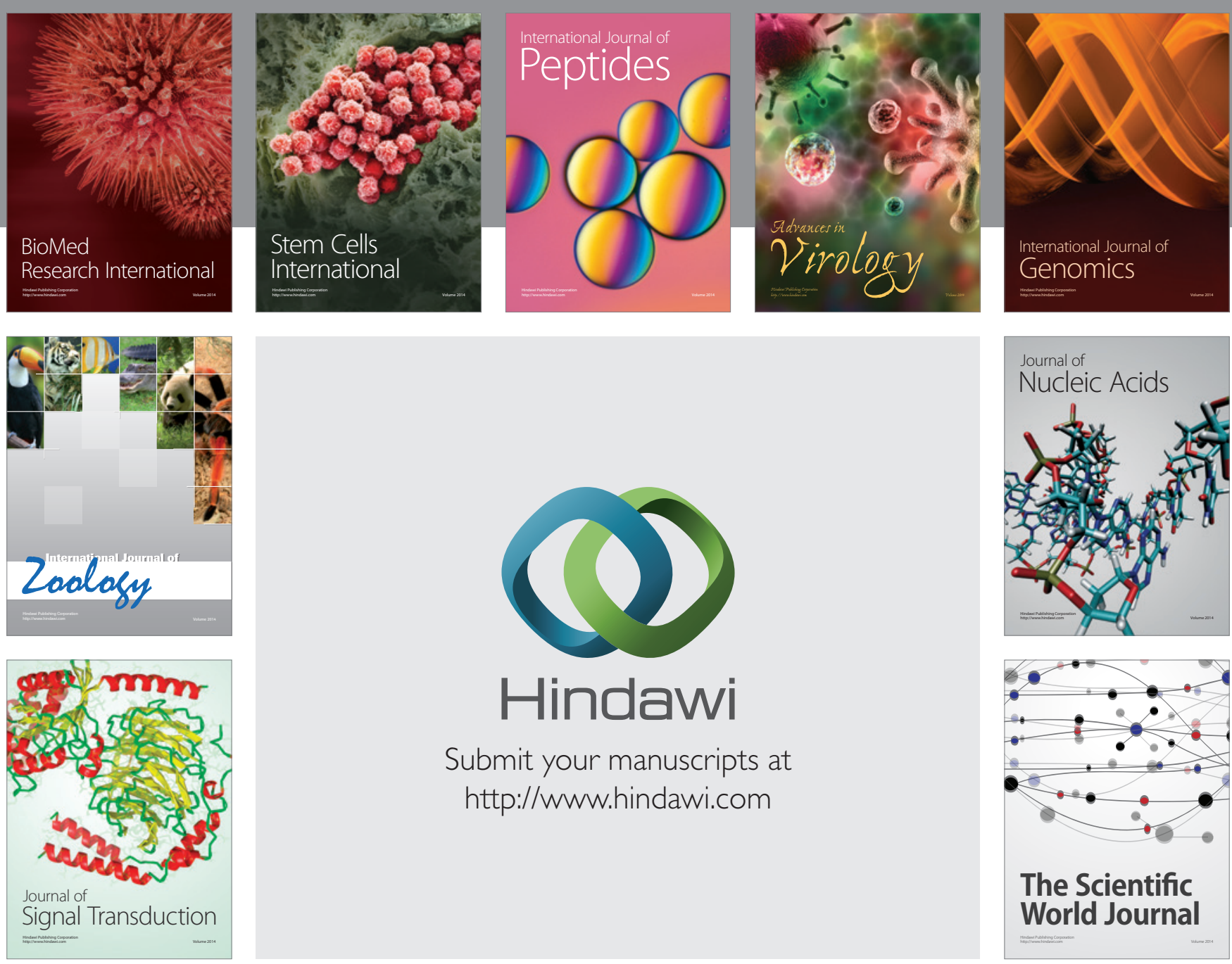

Submit your manuscripts at

http://www.hindawi.com
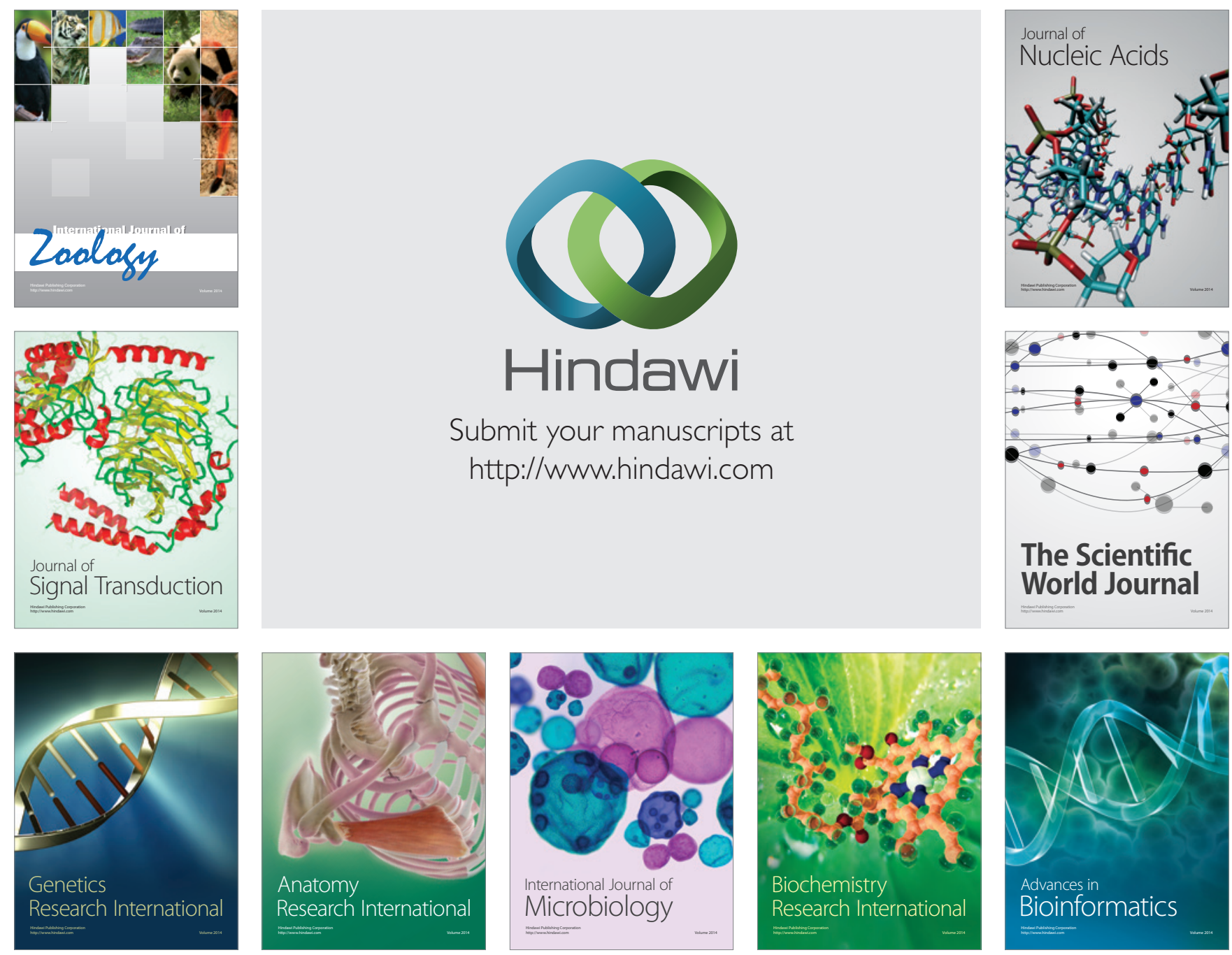

The Scientific World Journal
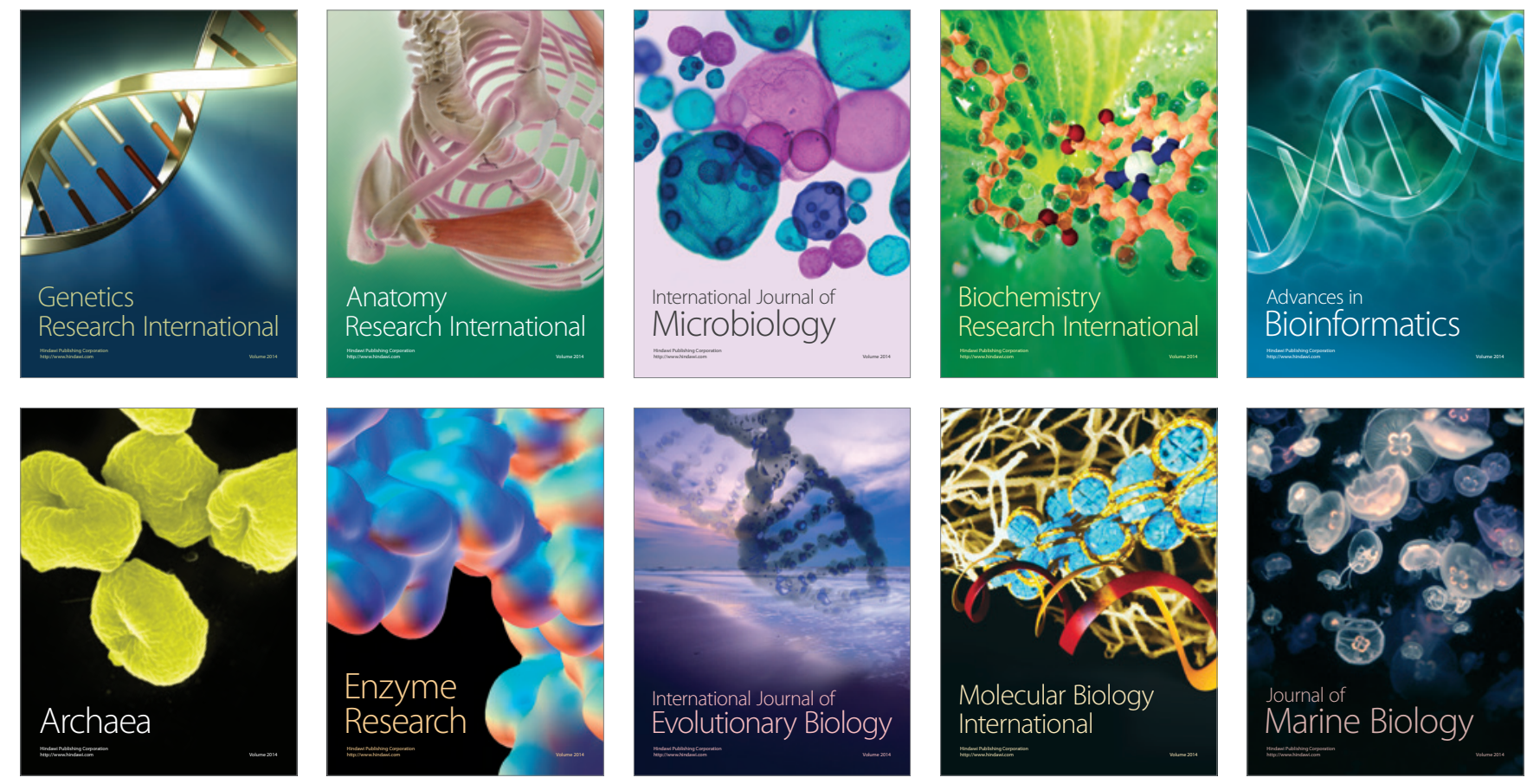